\title{
Bioactive Casein Phosphopeptides in Dairy Products as Nutraceuticals for Functional Foods
}

\author{
Gabriella Pinto, Simonetta Caira, Marina Cuollo, \\ Sergio Lilla, Lina Chianese and Francesco Addeo
}

Additional information is available at the end of the chapter

http://dx.doi.org/10.5772/50725

\section{Introduction}

Nutraceuticals, a term combining the words "nutrition" and "pharmaceutical", is a food or food product that provides medical or health benefits including the prevention and treatment of diseases. A functional food essentially provides a health benefit beyond the basic nutrition, whereas nutraceutical is used to describe an isolated or concentrated molecular extract of bioactive compounds. Milk is a unique food providing a variety of essential nutrients necessary to properly fuel the body. Inactive food proteins can release encrypted bioactive peptides in vivo or in vitro by digestive enzymatic hydrolysis. Bioseparation protocols offer unique possibilities for a number of application areas, e.g., hydrolyzate-based nutraceutical ingredients for functional foods, dietary supplements and medical foods.

Many ingredients are included in the wide range of nutraceuticals, such as essential amino acids, conjugated fatty acids, vitamins, minerals and polyphenols. They have already been patented and incorporated in functional foods and nutritional beverages. Such components are believed to improve overall health and well-being, reducing the risk of specific diseases or minimizing the effects of other health concerns. However, milk is devoid of flavonoids, the most common group of vegetable polyphenolic compounds, which act as antioxidants and free radical scavengers. In contrast, the ingestion of soy and green tea extract may reduce the risk of developing prostate cancer and may protect against various other types of cancer [1-2]. An interesting patented invention has made available an extended-release form of polyphenols and riboflavin (vitamin B2) coated with methylcellulose [3]. Coating slows down the release of polyphenols in the nutraceutical preparation [3]. Possible applications of coating technology could be extended to all of the bioactive peptides susceptible to digestive enzymes. For example, glutathione can be maintained in human blood at normal levels by supplying it as dry-filled capsules [4]. Nutrients and bioactive compounds may be 
microencapsulated by using mixtures of proteins or peptides and oils. Encapsulation of $\omega-3$ fatty acids (FA) enhances the stability and bioavailability of bioactive food ingredients [5]. By these means, new transparent bioavailable beverages containing $\omega-3$ rich oils, phospholipids and minerals in an oxidatively stable food system were created [6]. Iron or calcium casein phosphopeptides (CPP) were embedded in the chitosan lactate fiber as a protective agent against oil oxidation [6]. A recent patent relates to a nutraceutical composition consisting of a sweetener admixture for food or drink comprising calcium lactate, calcium acetate, vitamin D3 and sucralose (for fortified zero calorie formulation) or sugar (white/brown; for fortified sugar preparation) [7]. Milk proteins playing a physiological role include proteins such as $\beta$-lactoglobulin, $\alpha$-lactalbumin, immunoglobulins, lactoferrin, heat-stable proteose peptones, serum albumin and various acid soluble phosphoglycoproteins. Casein $(\mathrm{CN})$, representing $80 \%$ of total milk proteins, consists of four $\alpha_{\mathrm{s1}}-, \alpha_{\mathrm{s} 2-}, \beta-$, and $\kappa-\mathrm{CN}$ families in the approximate ratio 38:11:38:13. Research performed in recent years has shown that caseins and whey proteins are rich in encrypted biologically active peptides such as exorphins (casomorphins), CPP and immunopeptides [8]. The peptides are released by enzymes in the form of mature bioactive components or the precursors thereof [9]. They are 3- to 20-residue long peptides released during in vivo gastrointestinal digestion. Historically, the opioid peptides were discovered as the result of a systematic search for exogenous substances, namely (i) first discovered in 1979, opioid agonist peptides derived from milk proteins were characterized in 1986; (ii) in 1982, angiotensin-converting enzyme (ACE)inhibitory peptides were found to be antihypertensive peptides; (iii) then, fibrinogen-like sequences with antithrombotic activity were found; (iv) phagocytic activity and lymphocyte proliferation of numerous immunomodulating peptides were observed; (v) CPP facilitating the absorption of minerals, especially calcium, magnesium and iron were found; and (vi) antimicrobial peptides were discovered [10]. There are many milk peptides that possess multifunctional activities, i.e., they can play two or more hormone-like roles. Bioactive peptides grouped according to their function in human well-being are shown in Figure 1.

Nutraceutical products comprising short bioactive peptides showing in vitro or in vivo antimicrobial, ACE-inhibitory activity and/or antihypertensive and/or antioxidant activity are being considered for possible use by the pharmaceutical industry. The CN hydrolyzates could serve as food preservatives to reinforce the body's natural defenses or as pharmaceutical products for facilitating the control of blood and/or bacterial infections [12]. Much research has been devoted to increasing mineral transport by phosphorylated groups of peptides [13]. CPP in commercial hydrolysed casein (Tatua Cooperative Dairy Co. Ltd, New Zealand and Arla Foods Ingredients and Sweden) seem to help the absorption of chelated calcium, iron, copper, zinc and manganese in the intestine (Table 1). Thus, CPPbound amorphous calcium phosphate (ACP) displayed anticariogenic effect when added to dentifrices or oral care products by localizing calcium and phosphate ions at the tooth surface. Similarly, it has been claimed that a chewing gum or other confectionery product containing a combination of CPP-ACP and sodium bicarbonate as active ingredients can provide dental health benefits [14]. In experiments on humans, synthetic CPP-ACP nanocomplexes incorporated in mouth rinses and sugar-free chewing gums have been proven to be potential anticariogenic agents [15] (Table 1). 


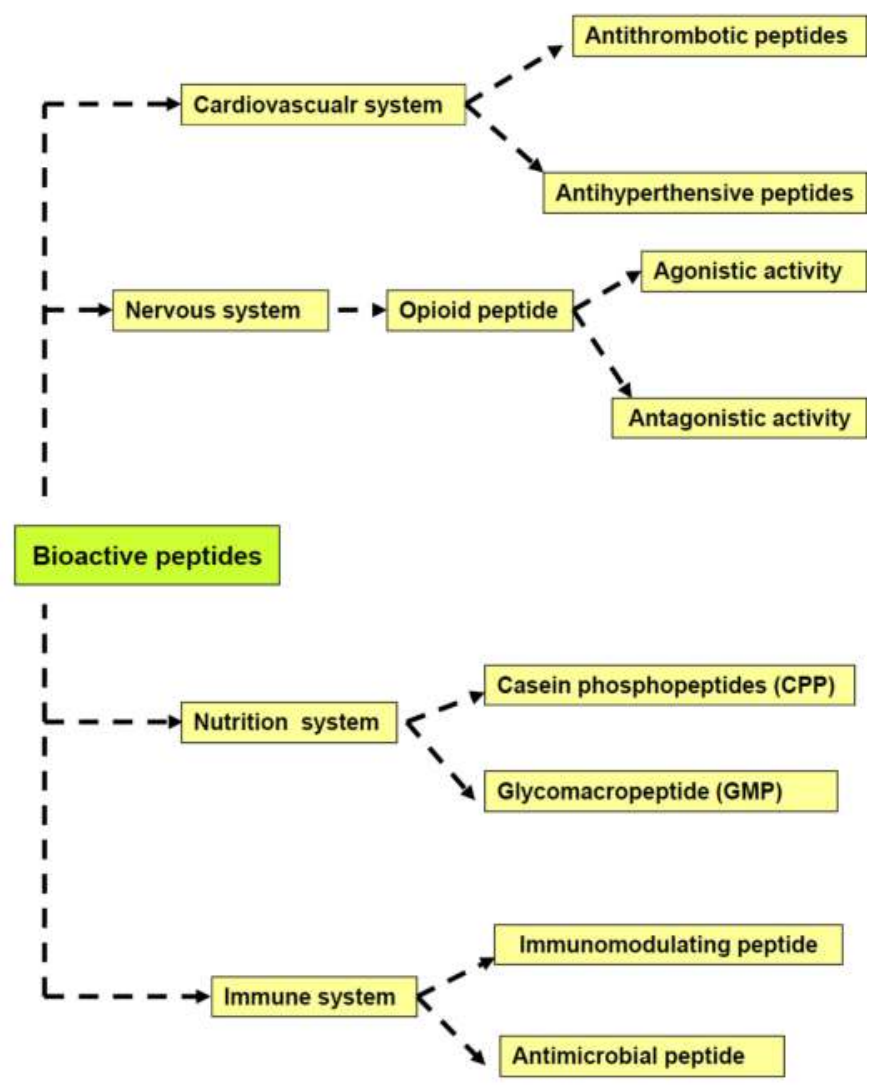

Figure 1. Main bioactivity of peptides formed by the enzymatic digestion of milk proteins (source: [11]).

\begin{tabular}{|l|l|l|l|l|}
\hline \multicolumn{1}{|c|}{ Brand name } & \multicolumn{1}{|c|}{ Product type } & $\begin{array}{c}\text { Claimed functional } \\
\text { bioactive peptides }\end{array}$ & Health/function claims & \multicolumn{1}{|c|}{ Manufacturer } \\
\hline HCP102/HCP 105 & Hydrolysate ingredient & CPP & Helps mineral absorption & Tatua (New Zealand) \\
\hline $\begin{array}{l}\text { Capolac } \\
\text { Recaldent }\end{array}$ & Hydrolysate ingredient & CPP & Helps mineral absorption & Arla Foods Ingredients (Sweden) \\
Recaldent & Chewing gum & ACP-CPP & Anticariogenic & Cadbury Adams (USA) \\
\hline
\end{tabular}

$\mathrm{ACP}=$ amorphous calcium phosphate; $\mathrm{CPP}=$ Casein phosphopeptides

Table 1. Commercial dairy products and ingredients with health or function claims based on CPP content (source: modified from [16]).

\section{Bioactive peptides released in vitro by the hydrolysis of milk proteins}

Peptides with various bioactivities can be produced according to two different methods: i) in vitro fermentation of milk inoculated with starter cultures and ii) in vitro digestion of milk proteins by one or more proteolytic enzymes. 
(i) The proteolytic system of lactococci is able to degrade milk proteins using cell-wallbound proteinases by releasing di-, tri-, and/or oligo-peptides and amino acids supporting the growth of bacteria. In addition, lactococcal peptidases released into the curd/cheese consequently to autolysis can further degrade the internalized peptides to amino acids [17]. The higher the exopeptidase activity in cheeses, the greater the age of the cheese [18]. Consistently, yogurt and other cultured dairy drinks have some of the highest counts of cells that actually survived and thus possessed the lowest number of peptides derived from the aminopeptidase activity. In a comprehensive review of literature, no enzyme with carboxypeptidase (CPase) activity has been reported for either lactococci or other LAB [1920]. The bacterial peptidases have different and partly overlapping specificities (Figure 2).

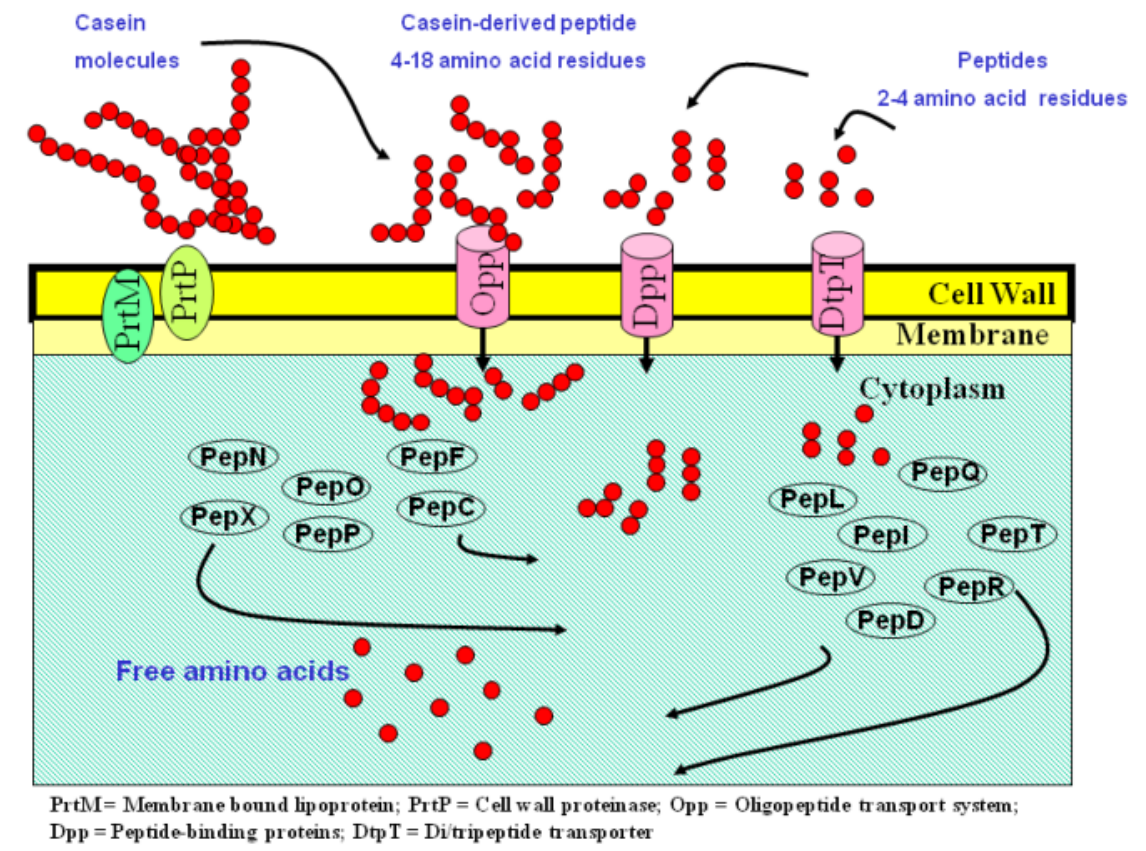

Figure 2. A simplified model presenting proteolysis, transport, peptidolysis and regulation of the proteolytic system of Lactococcus lactis on casein breakdown [20-22]. Intracellular peptidases PepO and PepF are endopeptidases, PepN/PepC/PepP are general aminopeptidases, PepX is X-prolyldipeptidyl aminopeptidase, PepT is tripeptidase, PepQ is prolidase, PepR is prolinase, PepI is proline iminopeptidase, and PepD and PepV are dipeptidases D and V. The role of PepN, PepC, PepI, PepP and PepA and PepO, PepF, PepX, PepQ, PepR, PepV, PepT and peptidolytic cycles are depicted schematically (various alternative routes of breakdown are possible for most peptides).

Although the intracellular endopeptidases PepN and PepC are unable to hydrolyze casein molecules, the X-prolyl dipeptidyl aminopeptidases (PepX) are active on oligopeptides hydrolyzing the internal bonds of casein-derived peptides. Taken together, these enzymes are able to remove the N-terminal residues from peptides, with the specificity primarily depending on the nature of the N-terminal amino acid [20-21]. Di- and tripeptides generated 
by endopeptidases, general aminopeptidases and PepX are next subjected to additional cleavage by the tripeptidase, PepT, and dipeptidases, PepV and PepD (Figure 2). Other peptidases with more specific substrate specificities include PepA, which liberates Nterminal acidic residues from 3- to 9-residue long peptides; PepP, which prefers tripeptides carrying proline in the middle position; PepR and PepI, which act on dipeptides containing proline in the penultimate position; PepQ, which cleaves dipeptides carrying proline in the second position; and PepS, which shows preference for peptides containing two to five residues with Arg or aromatic amino acid residues in the N-terminal position [20-21,23] (Figure 2). This proteolytic system is able to support LAB growth to high cell densities (109$10^{10} \mathrm{cfu} / \mathrm{mL}$ ) in milk containing only small amounts of hydrolytic products that are transportable into the cells for assimilation. Lb. helveticus and Lb. delbrueckii ssp. bulgaricus possess cell wall proteinase activity stronger than that of lactococci. The number of intracellular proteins released by St. thermophilus is greater than that by Lb. helveticus [24]. Proteins released in cheese from a starter-based thermophilic LAB, such as Lb. helveticus, $L b$. delbruecki subsp. lactis and Streptococcus salivarius subsp. thermophilus and Propionibacterium freudenreichii, have been identified using 2D-PAGE and mass spectrometry (MS) analysis [24]. Similarly, bioactive peptides have been determined using High Performance Liquid Chromatography (HPLC) and offline Matrix-Assisted Laser Desorption/Ionization Mass Spectrometry-Time-Of-Flight (MALDI-MS-TOF) [25]. These peptides were all generated from $\mathrm{CN}$ and released upon proteolysis depending on the bacterial strain [26]. In this manner, proteinases play a primary role, as they are able to generate specific bioactive

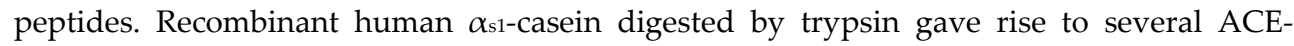
inhibitory peptides and calcium-binding CPP. These peptides did not form in cheese whey, although they can be formed from $\mathrm{CN}$ during fermentation using various commercial dairy starters [27]. The combination of the LAB bacteria and proteolytic enzymes could serve to increase the range of bioactive peptides.

(ii) In vitro hydrolysis of $\mathrm{CN}$ by pepsin and trypsin could produce many bioactive peptides. Pepsin, an endopeptidase with broad specificity, preferentially cleaves hydrophobic, preferably aromatic, residues. Trypsin specifically hydrolyses peptide bonds just after a lysine or an arginine residue of $\beta$-casein $\mathrm{A}^{1}$ and $\mathrm{A}^{2}$ variant (11 and 4 , respectively); $\kappa$ casein A and B (9 and 5); $\alpha_{\mathrm{s} 2}-\mathrm{CN}$ A (24 and 6); or $\alpha \mathrm{s} 1-\mathrm{CN}$ B (14 and 6). In this manner, tryptic hydrolysates of $\mathrm{CN}$ contain uneven peptides of up to $8159 \mathrm{Da}$ and also free amino acids [28]. We have demonstrated that $\mathrm{CN}$ hydrolysate by pepsin $(\mathrm{P})$ and trypsin $(\mathrm{T})$ in succession does not contain peptides with molecular mass greater than $2431 \mathrm{Da}$. $\beta-\mathrm{CN}$ resulted extensively hydrolyzed into a high number of oligopeptides by using proteases with well defined cleavage specificity. Controlled partial hydrolysis by proteinases could lead to the formation of partially degraded proteins critical for obtaining new functional products. The choice of digestion enzymes needs to be evaluated carefully because influences the hydrolysate final composition. A high number of peptides with antimicrobial, anti-hypertensive and opiod-like activity has been identified (Table 2), some of which exactly matched those described in the literature for potential bioactivity (Table 2). The potent opioid $\beta$-CM7 peptide retained part of its original opioid activity- 
like food hormone when progressively shortened. The synthetic $\beta$-casomorphin derivatives have been shown to be highly specific and potent $\beta$-type opioid receptor ligands [29].

We also performed sequential milk protein (powder sample) digestions using various endoproteases facilitating a consistent partial hydrolysis. The high degree of specificity in terms of cleaving peptide bonds exhibited by a cocktail of enzymes ( $\mathrm{P}, \mathrm{T}$ and $\mathrm{P} 432$ from Biocatalysts, U.K) yielded a limited number of CPP. After fractionation on an HA column,

\begin{tabular}{|c|c|c|c|}
\hline $\begin{array}{c}\text { Identity of bioactive } \\
\text { peptides } \\
\end{array}$ & Bioactivity & References & PT peptides \\
\hline $\begin{array}{l}\beta-\mathrm{CN}(\mathrm{f} 60-70) ;(\mathrm{f} 59-61) \\
\text { (f59-64); (f60-68) }\end{array}$ & Opiod & [29-30] & (f58-68); (f59-63); (f59-62) \\
\hline$\beta-\mathrm{CN}(\mathrm{f} 74-76)$ & \multirow{8}{*}{ ACE-Inhibitory } & \multirow{8}{*}{ [31-33] } & $(\mathrm{f} 69-80) ;(\mathrm{f} 71-80) ;(\mathrm{f} 75-80)$ \\
\hline$\beta-\mathrm{CN}$ (f80-90); (f84-86) & & & $\begin{array}{l}\text { (f80-88); (f81-89); (f81-88); (f81-92); (f81-93); } \\
\text { (f81-94) }\end{array}$ \\
\hline$\beta-\mathrm{CN}(\mathrm{f} 108-113)$ & & & $(f 108-103)$ \\
\hline$\beta-\mathrm{CN}$ (f140-143) & & & $(\mathrm{f} 139-142)$ \\
\hline$\beta-\mathrm{CN}(\mathrm{f} 177-183)$ & & & (f177-183); (f177-184); (f179-182) \\
\hline$\beta-\mathrm{CN}$ (f169-174) & & & (f169-176); (f172-176) \\
\hline$\beta-\mathrm{CN}(\mathrm{f} 193-198)$ & & & (f193-199) \\
\hline$\beta-\mathrm{CN}(\mathrm{f} 193-202)$ & & & (f193-202) \\
\hline$\beta-\mathrm{CN}(\mathrm{fl}-25) 4 \mathrm{P}$ & $\begin{array}{c}\text { Mineral carrier, } \\
\text { immunomodulatory, } \\
\text { cy tomodulatory }\end{array}$ & [34-38] & $\begin{array}{l}\text { (f12-17)1P; (f12-25)3P; (f12-25)4P; (f15-25)2P; } \\
\text { (f15-25)3P; (f19-25)1P; (f19-25)2P }\end{array}$ \\
\hline$\beta-\mathrm{CN}(\mathrm{f} 29-41) 1 \mathrm{P}$ & Mineral carrier & [13] & $(\mathrm{f} 33-42) 1 \mathrm{P} ;(\mathrm{f33}-43) 1 \mathrm{P} ;(\mathrm{f} 33-44) 1 \mathrm{P}$ \\
\hline$\beta-\mathrm{CN}$ (f84-86) & \multirow{3}{*}{ ACE-Inhibitory } & \multirow{3}{*}{ [31-33] } & $\begin{array}{l}\text { (f80-87); (f81-88); (f81-89); (f81-92); (f81-93); } \\
\text { (f81-94) }\end{array}$ \\
\hline$\alpha_{\mathrm{s} 1}-\mathrm{CN}(\mathrm{f} 23-34)$ & & & $(\mathrm{f} 24-32)$ \\
\hline$\alpha \mathrm{s}_{1}-\mathrm{CN}(\mathrm{f} 25-27)$ & & & $(\mathrm{f} 25-31)$ \\
\hline $\begin{array}{l}\alpha_{\mathrm{s} 1}-\mathrm{CN}(\mathrm{f} 90-96) ;(\mathrm{f} 90-95) ; \\
(\mathrm{f} 91-95)\end{array}$ & Opiod (agonist) & [39-41] & (f92-95); (f91-95); (f90-95) \\
\hline$\alpha_{\mathrm{s} 1}-\mathrm{CN}(\mathrm{f} 142-147)$ & \multirow{3}{*}{ ACE-Inhibitory } & \multirow{3}{*}[31-33]{} & (f142-145); (f143-146); (f143-150); (f144-149) \\
\hline$\alpha_{\mathrm{s} 1}-\mathrm{CN}(\mathrm{f} 157-164)$ & & & $(\mathrm{f} 155-164)$ \\
\hline$\alpha_{\mathrm{s} 1}-\mathrm{CN}(\mathrm{f} 194-199)$ & & & (f194-199); (f197-199); (f193-199) \\
\hline$\alpha_{\mathrm{s} 1}-\mathrm{CN}$ & \multirow{2}{*}{ Mineral carrier } & \multirow{2}{*}[13]{} & $(\mathrm{fl} 10-119) 1 \mathrm{P}$ \\
\hline$\alpha_{\mathrm{s} 1}-\mathrm{CN}$ & & & $(\mathrm{f} 41-55) 1 \mathrm{P} ;(\mathrm{f} 68-79) 2 \mathrm{P}$ \\
\hline$\alpha_{\mathrm{s} 2}-\mathrm{CN}(\mathrm{f} 174-179)$ & \multirow{2}{*}{ ACE-Inhibitory } & \multirow{2}{*}{ [31-33] } & $(\mathrm{f} 174-179)$ \\
\hline$\alpha_{\mathrm{s} 1}-\mathrm{CN}(\mathrm{f} 189-193)$ & & & $(\mathrm{f} 189-193)$ \\
\hline$\alpha_{\mathrm{s} 2}-\mathrm{CN}$ & \multirow{2}{*}{ Mineral carrier } & \multirow{3}{*}[13]{} & $(\mathrm{f} 138-146) 1 \mathrm{P}$ \\
\hline$\alpha_{\mathrm{s} 2}-\mathrm{CN}$ & & & (f124-137)2P; (f126-136)2P; (f126-137)2P \\
\hline$\kappa-\mathrm{CN}(\mathrm{f} 33-38)$ & Opiod (antagonist) & & $(\mathrm{f} 58-65) 1 \mathrm{P}$ \\
\hline
\end{tabular}

$\mathrm{PT}=$ Pepsin and Trypsin action; $\mathrm{P}=$ Phosphate group.

Table 2. Identity of bioactive peptides found in the PT digest of milk protein powder sample. The bioactivity of the peptide from which they derive and the references are reported. 
both non-CPP and CPP were identified as shown in Table 3. Different oxidation rates of Met residues in the same protein resulted in formation of the peptides with different molecular mass. In most cases, a single Met-containing peptide and its oxidized counterpart were identified. However, in many cases, when proteins contained several consecutive endoprotease sensitive bonds, different long peptides containing the same Met-oxidation site(s) were identified. The data in Table 3 suggest that the cocktail enzymes containing amino- and CPases, in addition to $\mathrm{P}$ and $\mathrm{T}$, progressively reduce the size of peptides without altering the degree of phosphorylation. Evaluation of protein/peptide quality can take advantage of the tandem MS for the detection of native, partly oxidized and partly dephosphorylated peptides.

By this means, phosphorylated peptides ( 2 and $3 \mathrm{P} / \mathrm{mole}$ ) of a precursor of lactophorin (LP) (28 kDa milk glycoprotein), proteose-peptone component 3, and glycosylation-dependent adhesion molecule 1 were detected. In addition, three low molecular weight non-CPP derived from LP were detected.

Native milk proteins used as the substrate for digestion by enzymes did not form CPP. This suggests that denatured LP and other whey proteins could have the tendency to form low molecular-mass peptide aggregates characterized by a poor solubility. For this reason, the use of milk protein and/or any milk substrate powder must be discouraged to eliminate phosphates and salts from the substrate. The enzymatic hydrolysis of the casein implies the use of endoproteases. However, the protein hydrolysate with alcalase is used in infant formulae, dietetic foods, nutraceuticals, ice creams, dressings, fermented products, yogurts, and personal care products. CPP released by alcalase are truncated with respect to those released by trypsin. The identified peptides can be categorized into two groups, one containing multiphosphorylated peptides and the other tri-, di- and mono CPP. Each group contained a number of variously long peptides due to the broad specificity of alcalase cleaving peptide bonds mainly on the carboxyl side of Glu, Met, Leu, Tyr, Lys, and Gln. The exoproteases responsible for the hydrolysis are inactivated by heating for $\sim 10 \mathrm{~min}$ to $\sim 85{ }^{\circ} \mathrm{C}$. The in vitro sequential use of pepsin, pancreatic proteases and extracts of human intestinal brush border membranes, mimicking the respective gastric, duodenal and jejuneal in vivo digestion of $\mathrm{CN}$, exhibited significant bioactive effects. A limited number of $\mathrm{CN}$ and whey protein peptides survived the in vitro simulated gastro-intestinal digestion. The anionic character seems to confer a marked resistance to multi-phosphorylated CPP hydrolysis by endoprotease. Ten out of $19 \mathrm{CPP}$ contained SerP available for binding minerals, and four of these peptides, $\alpha_{\mathrm{s} 1}-\mathrm{CN}$ (f5790)5P, $\alpha_{\mathrm{s} 1-\mathrm{CN}}(\mathrm{f} 56-90) 5 \mathrm{P}, \alpha_{\mathrm{s} 1-\mathrm{CN}}(\mathrm{f} 55-76) 5 \mathrm{P}, \beta-\mathrm{CN}$ (f1-52)5P, were reported for the first time in the $\mathrm{CN}$ digests [42]. Only $\beta-\mathrm{CN}$ (f1-25)4P, 3P and $2 \mathrm{P}$ survived the simulated gastrointestinal digest of $\mathrm{CN}$ [43].

The ingress of foreign material in general, such as CPP, across the mucosal brush-border into the enterocyte is conditioned by the efficient dephosphorylation of peptides by alkaline phosphatase. This aspect deserves more in-depth investigation. 


\begin{tabular}{|c|c|c|c|c|c|c|}
\hline \multirow{2}{*}{$\begin{array}{l}\text { Parent } \\
\text { protein }\end{array}$} & \multicolumn{2}{|c|}{ Molecular mass (Da) } & \multirow{2}{*}{ Start } & \multirow{2}{*}{ End } & \multirow{2}{*}{ Peptide s equence } & \multirow{2}{*}{ Peptide modifications } \\
\hline & Expected & Calculated & & & & \\
\hline \multirow{10}{*}{$\alpha_{\mathrm{s} 1}-\mathrm{CN}$} & 1222.5 & 1222.5 & 110 & -119 & (L)EIVPNSAEER(L) & $1 \mathrm{P}$ \\
\hline & 1517.8 & 1517.6 & 68 & -79 & (S)S EEIVPNS VEQK(H) & $2 \mathrm{P}$ \\
\hline & 1525.7 & 1525.5 & 41 & 53 & (L)SKDIGSESTEDQA(M) & $2 \mathrm{P}$ \\
\hline & 1586.6 & 1586.5 & 43 & 55 & (K)DIGSESTEDQAME(D) & 2P; Oxidation (Met) \\
\hline & 1672.7 & 1672.6 & 41 & 54 & (L)SKDIGSESTEDQAM(E) & 2P; Oxidation (M et) \\
\hline & 1785.8 & 1785.6 & 41 & 55 & (L)SKDIGS ES TEDQAME(D) & $2 \mathrm{P}$ \\
\hline & 1801.7 & 1801.6 & 41 & 55 & (L)SKDIGSES TEDQAME(D) & 2P; Oxidation (M et) \\
\hline & 1963.9 & 1963.8 & 39 & 55 & (N)ELSKDIGSES TEDQAME(D) & 1P; Oxidation (Met) \\
\hline & 1989.9 & 1989.7 & 37 & 52 & (K)VNELS KDIGSESTEDQ(A) & $3 \mathrm{P}$ \\
\hline & 2060.7 & 2060.7 & 37 & 53 & (K)VNELS KDIGS ES TEDQA(M) & $3 \mathrm{P}$ \\
\hline \multirow[t]{13}{*}{$\alpha_{\mathrm{s} 2}-\mathrm{CN}$} & 900.4 & 900.3 & 58 & 65 & $(\mathrm{~S}) \mathrm{SEESAEVA}(\mathrm{T})$ & $\mathrm{P}$ \\
\hline & 937.4 & 937.3 & 141 & -147 & (D)MES TEVF(T) & 1P; Oxidation (Met) \\
\hline & 1067.4 & 1067.3 & 57 & -65 & (S)SSEESAEVA(T) & $2 \mathrm{P}$ \\
\hline & 1089.5 & 1089.4 & 138 & -146 & (K)TVDMESTEV(F) & $1 \mathrm{P}$ \\
\hline & 1105.4 & 1105.4 & 138 & -146 & (K)TVDMESTEV(F) & 1P; Oxidation (Met) \\
\hline & 1252.6 & 1252.5 & 138 & -147 & (K)TVDMES TEVF(T) & 1P; Oxidation (Met) \\
\hline & 1410.6 & 1410.5 & 126 & -136 & (R)EQLSTSEENSK(K) & $2 \mathrm{P}$ \\
\hline & 1538.7 & 1538.6 & 126 & -137 & (R)EQLS TSEENSKK(T) & $2 \mathrm{P}$ \\
\hline & 1623.7 & 1623.6 & 1 & -13 & KNTMEHVSSSEES(I) & $2 \mathrm{P}$ \\
\hline & 1639.7 & 1639.5 & 1 & -13 & KNTMEHVSSSEES(I) & 2P; Oxidation (M et) \\
\hline & 1680.8 & 1680.6 & 124 & -136 & (L)NREQLSTSEENSK(K) & $2 \mathrm{P}$ \\
\hline & 1719.7 & 1719.5 & 1 & -13 & KNTMEHVSSSEES (I) & 3P; Oxidation (Met) \\
\hline & 1808.9 & 1808.7 & 124 & -137 & (L)NREQLSTSEENSKK(T) & $2 \mathrm{P}$ \\
\hline \multirow[t]{10}{*}{$\beta-\mathbf{C N}$} & 639.3 & 639.3 & 12 & -16 & (E)IVESL(S) & $1 \mathrm{P}$ \\
\hline & 900.5 & 900.4 & 19 & 25 & (S)S EESITR(I) & $1 \mathrm{P}$ \\
\hline & 1067.4 & 1067.4 & 18 & 25 & (S)S SEESITR(I) & $2 \mathrm{P}$ \\
\hline & 1354.6 & 1354.5 & 15 & 25 & (E)SLSS S EESITR(I) & $2 \mathrm{P}$ \\
\hline & 1434.6 & 1434.5 & 15 & 25 & (E)SLS S S EESITR(I) & $3 \mathrm{P}$ \\
\hline & 1447.7 & 1447.5 & 33 & 43 & (K)FQSEEQQQTED(E) & $1 \mathrm{P}$ \\
\hline & 1576.7 & 1576.6 & 33 & 44 & (K)FQSEEQQQTEDE(L) & $1 \mathrm{P}$ \\
\hline & 1689.8 & 1689.6 & 33 & 45 & (K)FQSEEQQQTEDEL(Q) & $1 \mathrm{P}$ \\
\hline & 1775.8 & 1775.7 & 12 & 25 & (E)IVESLSSSEESITR(I) & $3 \mathrm{P}$ \\
\hline & 1855.6 & 1855.6 & 12 & 25 & (E)IVES LS S S EESITR(I) & $4 \mathrm{P}$ \\
\hline \multirow[t]{2}{*}{$\kappa-\mathrm{CN}$} & 968.4 & 968.4 & 145 & -152 & (A)TLEDS PEV(I) & $1 \mathrm{P}$ \\
\hline & 1734.7 & 1734.7 & 147 & -161 & (L)EDS PEVIESPPEINT(V) & $1 \mathrm{P}$ \\
\hline \multirow[t]{4}{*}{ Lactophorin } & 1226.5 & 1226.51 & 34 & -43 & (L)SKEPSIS RED(L) & $1 \mathrm{P}$ \\
\hline & 1306.6 & 1306.5 & 34 & -43 & (L)SKEPS IS RED(L) & $2 \mathrm{P}$ \\
\hline & 1419.6 & 1419.56 & 34 & 44 & (L)SKEPS IS REDL(I) & $2 \mathrm{P}$ \\
\hline & 1499.7 & 1499.5 & 34 & 44 & (L)S KEPS IS REDL(I) & $3 \mathrm{P}$ \\
\hline
\end{tabular}

Phosphoserine residues are coloured red.

Table 3. Native and partly Met-oxidized CPP isolated from a three enzyme (Pepsin, trypsin and P432) milk protein hydrolyzate. 


\section{In vivo digestion of casein, formation of CPP and their physiological importance}

Among the biologically active peptides, CPP characterized by SerP and/or ThrP residues account for $\sim 30 \%$ of monoesters of hydroxyl amino acids. They mainly occur in the Ser/ThrXaa-SerP/Glu/Asp sequence consensus, where Xaa is any amino acid residue but Pro. The three-phosphorylated motif -SerP-SerP-SerP-Glu-Glu- occurs in $\alpha_{\mathrm{s} 1}-\mathrm{CN}$ (f66-70), $\alpha_{\mathrm{s} 2-\mathrm{CN}}$ (f8-12), $\alpha_{\mathrm{s} 2}-\mathrm{CN}$ (f56-60), and $\beta-\mathrm{CN}$ (f17-21). According to the current $\mathrm{CN}$ nomenclature, bovine $\alpha_{\mathrm{s} 1}-\mathrm{CN}$, $\alpha_{\mathrm{s} 2}-\mathrm{CN}, \beta-\mathrm{CN}$, and $\kappa-\mathrm{CN}$ possess $8-9,11-13,4-5$, and 1-2 phosphate $(\mathrm{P})$ residues, respectively, and the $P$ number could change according to the casein variant [44]. For example, $\beta-C N$ D has one SerP residue less than the A counterpart due to the substitution $\mathrm{Lys}^{18} \rightarrow \mathrm{Ser}^{18}$.

The in vivo digestion of milk proteins takes place mainly in the stomach under the action of pepsins, gastric digestive proteinases that are able to digest $\sim 20 \%$ proteins. Afterwards, the pepsin digests pass to the duodenum where peptides are further hydrolyzed by pancreatic enzymes. The digestion is completed by membrane proteases and a variety of peptidases embedded in the brush border of the small intestine and released by the intestinal microflora. These peptidases release an amino acid residue or a dipeptide from the $\mathrm{N}$ - and C-terminal side of oligopeptides [45-47]. Phosphatase(s) located in the brush border of the apical membrane of enterocytes, act(s) in removing phosphate groups, thus promoting partial or full peptide dephosphorylation of peptides in different body districts. The phosphorylated sequence is responsible, at the intestinal $\mathrm{pH}$, for binding $\mathrm{Ca}^{++}, \mathrm{Zn}^{++}$, and $\mathrm{Mg}^{++}$and for the in vivo resistance of the complex to gastrointestinal proteases [48]. Fe complexed to $\beta-\mathrm{CN}$ (f15-25)4P was scarcely hydrolyzed throughout the digestion, suggesting that the coordination of iron ions to CPP inhibits the action of both phosphatase and peptidases [49]. Brush border enzyme alkaline phosphatase activity could improve the absorption of Fe complexed CPP by releasing Fe from peptides. Moreover, Fe complexed to $\beta$-CN CPP was absorbed more than Fe complexed to $\alpha_{\mathrm{s} 1-}$ CN CPP [50]. The differences in protein composition between cow and breast milk could explain some of the differences in the Fe bioavailability of the latter [50]. Iron deficiency, a major worldwide nutritional problem, can be reduced by CPP. Fe complexed CPP prevents the formation of poorly absorbed high molecular weight ferric hydroxides. Zinc absorption can also be enhanced by the formation of $\mathrm{Zn}$ complexed to $\mathrm{CCP}$, in particular to $\beta-\mathrm{CN}$ (f1-25)4P [51]. Some portion of the mineral complexed CPP formed in the small intestine was resistant to the digestive and enteric bacteria enzymes and found in the feces of rats fed a casein-based diet [52]. Although literature data regarding intestinal CPP absorption are conflicting, the peptides seem to interact directly with the plasma membrane. One possible mode of CPP action on the transmembrane flux of calcium is that CPP might insert themselves into the plasma membrane and form their own calcium selective channels or act as calcium-carrier peptides rapidly internalized via endocytosis or other processes and eventually provide ionized calcium in the cytosol [53]. Cellular uptake studies of fluorine-18 labeled CPP in human colorectal adenocarcinoma cell line (HT-29) and human head and neck squamous cell carcinoma line $(\mathrm{FaDu})$ cells at $37^{\circ} \mathrm{C}$ and $48^{\circ} \mathrm{C}$ showed a poor cell penetration because of the poor transport of the phosphopeptides through the cell membrane [54]. The results from in vivo studies are still too controversial, as there are many factors affecting Ca availability, such 
as the various co-present dietary compounds in the intestinal lumen [55]. Despite the vigor of the saturable active transport process by the duodenum, most of the absorption of ingested calcium occurs in the ileum ( $88 \%$ of calcium), jejunum (4\%) and duodenum (8\%) [56]. An important factor determining the contribution of the ileum to overall calcium absorption is the relatively long transit time of calcium in the segments of the small intestine, accounting for approximately $102 \mathrm{~min}$ in the ileum and $6 \mathrm{~min}$ in the duodenum [57]. The higher absorption of calcium occurred when inorganic $\mathrm{P}$ was added to the Ca-CPP preparation. CPP exhibit a potent ability to form soluble complexes with $\mathrm{Ca}^{2+}$ and other trace elements, preventing the formation of Ca-phosphate precipitate in the intestine. CPP could limit the inhibitory effect of phosphate on Ca availability and increase Ca transport across the distal small intestine [55]. All components of the diet reaching the ileum make calcium soluble or keep it in solution within the ileum. Several molecules, particularly CPP, stimulate the passive diffusion of minerals. $\mathrm{CPP}$ have been for the first time detected in human ileostomy fluid, confirming their ability to survive gastrointestinal passage into the human distal ileum [58]. CPP released during milk digestion appeared to be stable for up to $8 \mathrm{~h}$ in ileostomy contents [58]. The in vivo formation of bovine CPP was demonstrated in the small intestinal fluid of minipigs after ingestion of a diet containing casein [59] and in the stomach and duodenum after ingestion of milk or yogurt [60]. The in vivo survival of CPP to the prolonged intestinal passage in the distal small intestine is a prerequisite for their function as bioactive substances [58]. CPP are protected from degradation in the gut by the milk matrix, provided that they are ingested as milk constituents and not as isolated CPP. Whole casein or individual casein fractions are used as raw materials to obtain CPP as dietary supplements. Ca could be bound to either SerP or Glu residues [61], suggesting that CPP may enhance the solubility of calcium in the intestinal lumen, thereby increasing the mineral availability for absorption in the small intestine $[62,13]$. Chemically synthesized CPP, i.e., $\beta-\mathrm{CN}$ (f1-25)4P and $\alpha \mathrm{s} 1-\mathrm{CN}$ (f59-79)5P, carrying the characteristic cluster Ser(P)-Ser(P)-Ser(P)-Glu-Glu, increase the intracellular calcium uptake by the human cultured HT-29 tumor cells [63], Caco-2 cells [64] and osteoblasts [65]. A more pronounced effect has been observed for $\beta$-CN-derived peptides than for $\alpha_{\mathrm{s} 1}-\mathrm{CN}$-counterparts. It has been suggested that CPP promote calcium binding, which would depend on the structural conformation conferred by the two phosphorylated 'acidic motif' and the N-terminal sequence of $\beta-\mathrm{CN}$ [63].

Dental caries are initiated via the demineralization of tooth hard tissue by organic acids directly from the diet or produced from fermentable carbohydrate by dental plaque cariogenic bacteria. CPP can help to replace the minerals that were previously lost consequently to caries [66-67]. Hence, there is a great interest in developing CPP as nutraceutical ingredients for the formulation of functional foods.

\section{CPP enrichment by different techniques}

CPP preferably comprise components released by four different casein families, each having a molecular weight greater than $500 \mathrm{Da}$. Multiply and singly, tryptic CPP can be simultaneously detected using MALDI-TOF, and the location of phosphate groups by a combination of tandem mass spectrometry and computer-assisted database search programs, such as SEQUEST (Trademark, University of Washington, Seattle Wash) [68-69]. 
Nano-electrospray MS/MS has been used for phosphopeptide sequencing and exact determination of phosphorylation sites [70]. However, mass spectrometric analysis of proteolytic digests of proteins rarely provides full coverage of the phosphorylated sequence, with parts of the sequence often going undetected. In addition, protein phosphorylation is often sub-stoichiometric, such that ionization of CPP present in lower abundance in complex hydrolysates is ordinarily suppressed by strongly ionizable non-phosphorylated peptides. The MALDI-MS desorption/ionization efficiency for phosphopeptides was reported to be an order of magnitude lower than that recorded for the non-phosphorylated counterpart, and ionization became more difficult as the number of phosphate groups increased [71]. Direct analysis of phosphopeptides utilizes two orthogonal MS scanning techniques, both based on the production of phosphopeptide-specific marker ions at $\mathrm{m} / \mathrm{z} 63$ and/or 79 in the negative ion mode. These scanning methods combined with the liquid chromatography (LC)electrospray mass spectrometry (ESI) and nano-electrospray MS/MS allow the selective detection and identification of phosphopeptides even in complex proteolytic digests. Thus, even when the signal of the phosphopeptide is indistinguishable from the background, as in the conventional MS scan, low-abundant and low-stoichiometric phosphorylated peptides can be selectively determined in the presence of a large excess of non-phosphorylated peptides. This strategy is particularly well suited to phosphoproteins that are phosphorylated to varying degrees of stoichiometry at multiple sites [72]. However, the identification and characterization of phosphoproteins would be greatly improved using selective enrichment of CPP prior to MS analysis. An ancient technique for phosphoprotein enrichment consisted of the precipitation of phosphopeptides as insoluble barium salts and recovery by centrifugation, as according to the Manson \& Annan method [73]. Highthroughput phosphoproteome technologies currently rely on combining pre-separation of proteins, most commonly by high-resolution two-dimensional polyacrylamide gel, in-gel tryptic cleavage of proteins, and subsequent MALDI-TOF or ESI-MS/MS mass spectrometry analysis of peptides [74]. The high resolving power of 2-DE with the sensitive MS requires extensive manual manipulation of samples. Alternative methods are based on chemical derivatization. For example, for $\beta$-elimination, a strong base such as $\mathrm{NaOH}$ or $\mathrm{Ba}(\mathrm{OH})_{2}$ is used to cleave the phosphoester bonds of phosphoserine and phosphothreonine and form dehydroalanine or dehydroaminobutyric acid, respectively, each able to react with different nucleophiles, such as ethanedithiol (EDT) or dithiothreitol (DTT). This procedure provides a considerably simpler method to enrich CPP. By using cross-linking reagents with affinity tags, such as biotin, interfering non-cross-linked peptides are eliminated, and CPP are highly enriched [75]. Although the chemical derivatization methods are highly selective, they are not widely applied in phosphoproteome studies due to sample loss by the multiple reaction steps and unavoidable side reactions [76]. Immobilized metal-ion affinity chromatography (IMAC, with $\mathrm{Fe}^{3+}, \mathrm{Ga}^{3+}, \mathrm{Ni}^{2+}$ and $\mathrm{Zr}^{4+}$ metal ions) and metal oxide affinity chromatography (MOAC, with $\mathrm{TiO}_{2}, \mathrm{ZrO}_{2}, \mathrm{Al}_{2} \mathrm{O}_{3}$ and $\mathrm{Nb}_{2} \mathrm{O}_{5}$ ) have been widely used for the quantitative binding of CPP on resin or adsorbent. Iminodiacetic acid (IDA, a tridentate metal-chelator) or nitrilotriacetic acid (NTA, a quadradentate metal chelator) are often used as IMAC functional matrices reacting with multivalent metal ions to form chelated ions with positive charges useful for the purification of phosphopeptides. Usually $\mathrm{Fe}^{3+}, \mathrm{Ga}^{3+}$ and $\mathrm{Al}^{3+}$ are bound to a chelating support prior to fractionating the complex mixture of peptides 
before MS analysis [77-78]. $\mathrm{Ga}^{3+}$ showed selectivity for CPP higher than $\mathrm{Fe}^{3+}$ and $\mathrm{Al}^{3+}[77,79]$. Phosphopeptides bound to IMAC resin are successively recovered in the column effluent by increasing either $\mathrm{pH}$ or the phosphate concentration in the buffer [80]. The negatively charged CPP selectively interact with $\mathrm{TiO}_{2}$ microspheres via bidentate binding at the dioxide surface [81-83]. $\mathrm{TiO}_{2}-\mathrm{MOAC}$ showed higher specificity than immobilized gallium $\left(\mathrm{Ga}^{3+}\right)$, immobilized iron $\left(\mathrm{Fe}^{3+}\right)$, or zirconium dioxide $\left(\mathrm{ZrO}_{2}\right)$ affinity chromatography for phosphopeptide enrichment. The main problem associated with the chelating resins is the metal-ion leaching, which leads to CPP loss during the enrichment procedure. The selectivity of these methods was somewhat compromised by the detection of several acidic non-CPP that were also retained by the $\mathrm{TiO}_{2}$ column [84]. To overcome this drawback, the carboxyl groups are methyl esterified which eliminates the non-specific adsorption of acidic peptides on IMAC [85]. Considerable efforts have been expended to remove acidic non-CPP by washing the resin with 2,5-dihydroxybenzoic acid (DHB) [86] or phthalic acid [87]. It has been found that aliphatic hydroxyl acid modified metal oxide works more efficiently and more specifically than aromatic modifiers such as DHB and phthalic acid in titania and zirconia MOC [88]. However, all affinity techniques developed for the current enrichment strategies of CPP gave reproducible but incomplete results due to poor binding of low concentrations of CPP and the insufficient recovery of multiple phosphorylated peptides [89]. Recently, a specific hydroxyapatite (HA)-based enrichment procedure has been developed for complex mixtures of phosphoprotein/CPP [90]. Salt such as calcium phosphate, also occurring in bone and tooth tissue in the HA form, with the formula [Ca10 $\left.\left(\mathrm{PO}_{4}\right)_{6}(\mathrm{OH})_{2}\right]$, has been previously used to enrich bone proteins [91]. The phosphate groups of phosphoproteins interact with crystalline lattice $\mathrm{Ca}^{2+}$ [92] more strongly than do the carboxyl groups [93]. Moreover, increasing protein phosphorylation leads to tighter binding of the proteins/CPP to HA [92]. One might conclude that the affinity of the multi-phosphorylated proteins/peptides for HA is significantly higher than that of the same components with lower phosphorylation. Essentially, the HA-based protocol immobilizes on HA microgranules proteins/peptides through their phosphate groups, while the non phosphorylated components are washed out using various buffers. In a previous article, CPP immobilized on HA were progressively eluted, increasing phosphate in the elution buffer, and then identified by off-line MALDI-MS [94]. This procedure was accelerated, and loss during elution was minimized by spotting HA-CN/CPP microgranules onto a MALDI target and analyzing the peptides directly by MALDI-TOF [90]. This method was useful for measuring the phosphorylation level of phosphoproteins/CPP quickly, with less than $2 \mathrm{~h}$ elapsing from the fractionation of the protein/CPP to the readout of the MALDI spectra (excluding the trypsinolysis step).

The more important advantages of the procedure are the possibility of (1) detecting phosphorylated proteins/peptides even in complex mixtures, (2) determining phosphorylated sites and those dephosphorylated by phosphatase, (3) attaining information regarding weakly and heavily phosphorylated peptides and (4) adding the HA-CPP complex directly to food, which is enabled by the use of an edible resin such HA [90]. Moreover, use of available commercial CPP preparations by the food industry is difficult for three primary reasons: i) the matrix bound to CPP is often not edible and such products can be hazardous; ii) the 
preparation of $\mathrm{CPP}$ is a long and a laborious procedure that requires cumbersome and expensive manipulation; and iii) CPP have an unpleasant taste even in modest amounts, which disadvantageously limits their direct utilization as a human food ingredient. A novel HA-based method for food grade CPP preparation has been performed on tryptic digests of casein. HA captured all CPP free of non-CPP [90]. There were approximately $32 \mathrm{HA}$ bound CPP, and all non-CPP peptides were eluted [90]. HA-based enrichment procedure has been successfully applied to phosphopeptide recovery from complex biological fluids such as human serum thus providing a great source of potential biomarkers of disease. Four primary phosphopeptides derived from fibrinogen were enriched from human serum (Figure 3a-b, Table 4). A similar set of phosphorylated peptides was previously obtained using a modified IMAC strategy coupled to iterative mass spectrometry-based scanning techniques [95], using the titanium ion-immobilized mesoporous silica particles and MALDI-TOF [96] and cerium ion-chelated magnetic silica microspheres [97].

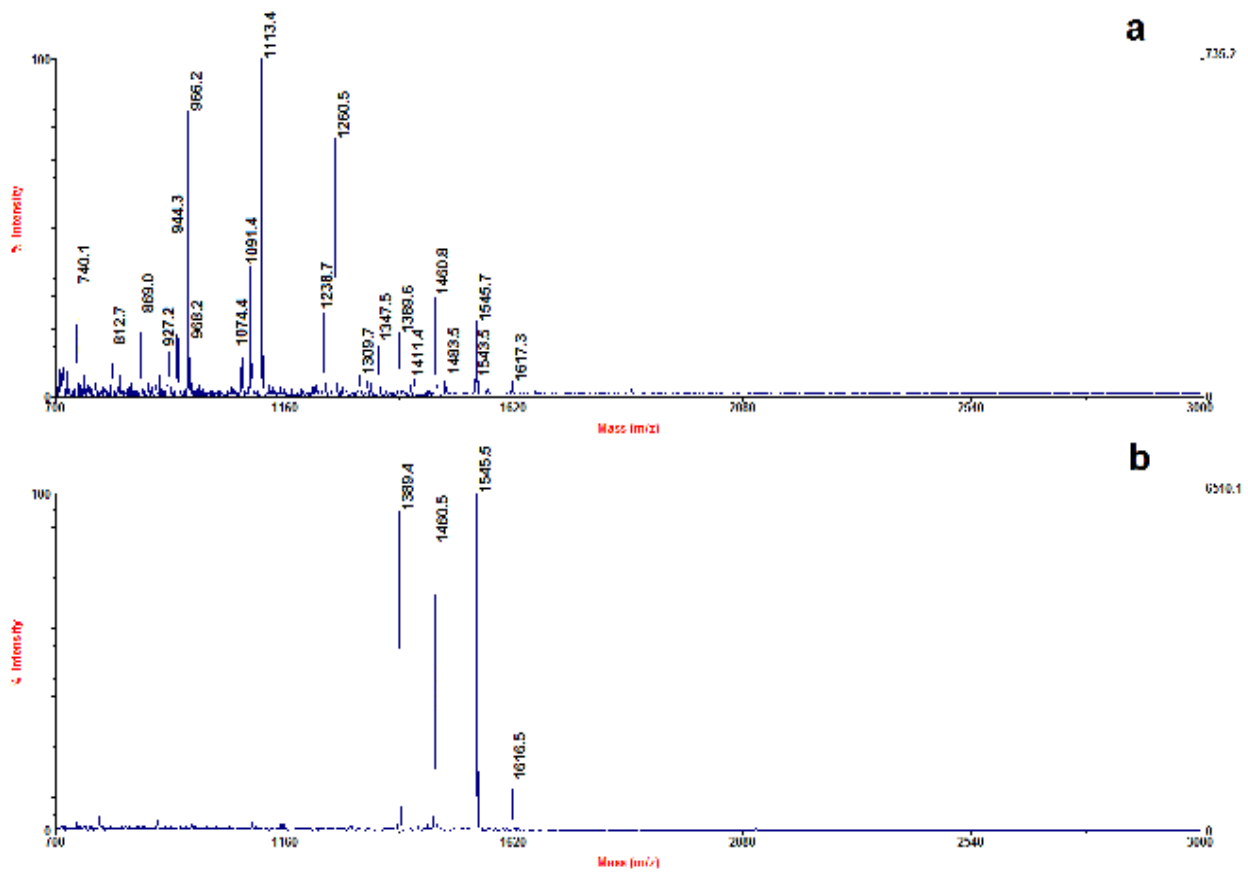

Figure 3. MALDI-MS-TOF spectra for the human serum before (a) and after (b) enrichment by HA (insert is the zoomed between 700 and $3000 \mathrm{Da}$ ).

Fibrinopeptide A (FPA) (f1-16)1P, (SerP3), a 16-residue long peptide (1615 Da) (Table 4), is the segment anchored on the thrombin surface [98]. The other three phosphopeptides, (f1- 
15)1P, (f2-15)1P and (f2-16)1P (Table 4), are hydrolytic products of FPA. The serum level of fibrinogen and its hydrolytic products may reflect the expression and activation of enzymes including kinase, phosphatase, and protease [99]. An altered ratio of FPA (f2-15) and FPA (f1-16) is detected in patients affected by hepatocellular carcinoma; the $\mathrm{D}^{2}[\mathrm{pS}]$ GEGDFLAEGGGV ${ }^{15}$ peptide is upregulated, and the $\mathrm{A}^{1} \mathrm{D}[\mathrm{pS}]$ GEGDFLAEGGGVR ${ }^{16}$ peptide is down-regulated greatly. The other two peptides, $\mathrm{A}^{1} \mathrm{D}[\mathrm{pS}] \mathrm{GEGDFLAEGGGV}{ }^{15}$ and $\mathrm{D}^{2}[\mathrm{pS}]$ GEGDFLAEGGGVR ${ }^{16}$, varied only slightly between the two groups [96]. The proportions of fibrinogen and their phosphorylation products offer new opportunities for basic research in exploring new frontiers in bio-marker discovery.

\begin{tabular}{|c|c|c|c|}
\hline \multicolumn{2}{|c|}{ Molecular Mass (Da) } & Fibrinogen $\boldsymbol{\alpha}$-chain sequence & $\begin{array}{c}\text { Phos phorylation } \\
\text { sites }\end{array}$ \\
\cline { 1 - 2 } Theoretical & Meas ured $\mathbf{M H}^{+}$ & & 1 \\
1388.5 & 1389.4 & $\mathrm{D}^{2}$ SGEGDFLAEGGGV $^{15}$ & 1 \\
1459.5 & 1460.5 & $\mathrm{~A}^{1} \mathrm{DSGEGDFLAEGGGV}^{15}$ & 1 \\
1544.6 & 1545.5 & $\mathrm{D}^{2}$ SGEGDFLAEGGGVR $^{16}$ & 1 \\
1615.6 & 1616.5 & $\mathrm{~A}^{1} \mathrm{DSSGGDFLAEGGGVR}^{16}$ & 1 \\
\hline
\end{tabular}

Phosphoserine residues are coloured red.

Table 4. Identification of phosphorylated fibrinogen fragments from human serum immobilized on HA.

\subsection{CPP in commercial milk as specific indicators of heated milks}

Because of the lower value, the addition of UHT and milk powder to raw or pasteurized milk is prohibited (EU Directives 92/46 CEE and 94/71 CEE) for cheese milk. The intensity of heat treatment was found to correlate with the furosine content. Glycated proteins and peptides formed during the initial stages of the Maillard reaction are indirectly evaluated through the furosine content [100-101]. The Amadori compound formed upon the reaction of lysine residue with a lactose molecule will prevent the digestive enzymes from reaching the binding sites. Native and lactosylated forms of $\beta-\mathrm{CN}$ (f1-28)4P, (f1-27) $4 \mathrm{P}$ and $\alpha_{\mathrm{s} 2}-\mathrm{CN}$ (f124) $4 \mathrm{P}$, although typical of UHT milk and milk powder, are missing in raw, pasteurized milk $\left(71.7^{\circ} \mathrm{C}\right.$ for $\left.15 \mathrm{~s}\right)$ and intensely pasteurized milk. The lactosylated peptides that varied with heat treatment characterize UHT milk added in amounts not lower than $10 \%$ to raw and pasteurized milk [102]. Milk delactosed with microbial $\beta$-galactosidase did not suppress the Maillard reaction; indeed, the furosine concentration increased to 35-400 mg/100 g of protein [103]. As expected, a lactose-reduced UHT milk had $\beta-\mathrm{CN}$ (f1-28)4P glycated mainly by its monosaccharides (Figure 4a).

Therefore, the nonenzymatically glycated CPP derived from the reaction of one molecule of glucose or galactose with a lysine residue $(\mathrm{m} / \mathrm{z}$ 3641) can be considered to be the signature peptide of lactose-reduced milk (Figure 4). 

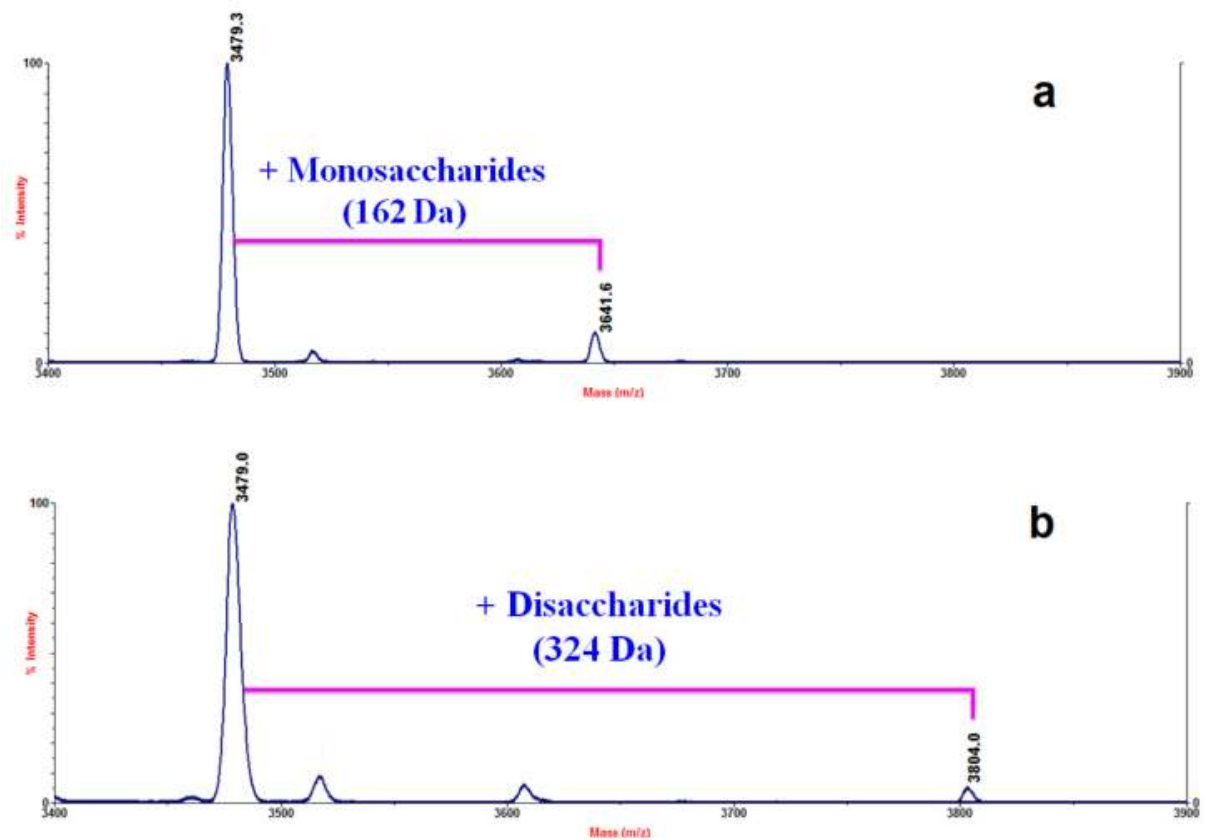

Figure 4. Enlarged view of the MALDI spectrum of $\beta-\mathrm{CN}(\mathrm{f} 1-28) 4 \mathrm{P}\left(\mathrm{MH}^{+}=3479 \mathrm{Da}\right)$ signature glycosylated CPP in lactose-reduced UHT milk (a) and lactosylated CPP in UHT milk (b). The mass differences corresponded to lactose and glucose/galactose residues.

\subsection{CPP in yogurt}

Yogurt is a fermented milk defined as the "food produced by culturing one or more of the optional dairy ingredients (cream, milk, partially skimmed milk, and skim milk) with a characteristic bacteria culture that contains the lactic acid-producing bacteria, Lactobacillus delbrueckii subsp. bulgaricus and Streptococcus thermophilus". A heat treatment of $90{ }^{\circ} \mathrm{C}$ for 10 min is considered optimal to obtain a good quality yogurt [104], and the addition of milk powder increases the content of furosine to more than $300 \mathrm{mg} / 100 \mathrm{~g}$ protein [105]. In yogurt, enzymes could give rise to the liberation of a particularly high number of bioactive peptides, among them CPP, which could be partly due to LAB proteolytic activity. Comparison of $\mathrm{CPP}$ in raw, pasteurized and intensely heated milks has previously shown that there is a plethora of milk peptides among which a few were glycosylated CPP [102]. Yogurt is prepared from intensely heated milk instead of low-pasteurized drinking milk. The CPP of two preparations were enriched on HA and analyzed by MALDI-TOF (Table 5). The proportion of CPP with molecular masses between 2.5 and $4 \mathrm{kDa}$ was significantly higher in yogurt than in pasteurized milk as shown in Table 5. Only four fragments of CPP-derived peptides produced during yogurt preparation occur in pasteurized milk (Table 5). 


\begin{tabular}{|c|c|c|c|c|}
\hline \multicolumn{2}{|c|}{ Molecular Mass (Da) } & \multirow{2}{*}{ CPP sequence } & \multirow{2}{*}{\multicolumn{2}{|c|}{\begin{tabular}{c|c} 
Yogurt & $\begin{array}{c}\text { Pasteurized } \\
\text { milk }\end{array}$ \\
Relative Intensity
\end{tabular}}} \\
\hline Meas ured $\mathrm{MH}^{+}$ & Theoretical & & & \\
\hline \multicolumn{5}{|c|}{$\alpha_{s 1-C N}$ derived CPP } \\
\hline 1327.5 & 1326.4 & $\alpha_{\mathrm{s} 1}-\mathrm{CN}(\mathrm{f} 44-54) 2 \mathrm{P}$ & 0.3 & n.d. \\
\hline 5009.1 & 5008.7 & $\alpha_{\mathrm{si}}-\mathrm{CN}(\mathrm{f} 39-79) 6 \mathrm{P}$ & 0.6 & n.d. \\
\hline 5089.3 & 5088.7 & $\alpha_{\mathrm{s} 1}-\mathrm{CN}(\mathrm{f} 39-79) 7 \mathrm{P}$ & 1.2 & n.d. \\
\hline 6959.0 & 6958.7 & $\alpha_{\mathrm{s} 1}-\mathrm{CN}(\mathrm{f} 35-90) 8 \mathrm{P}$ & 0.6 & n.d. \\
\hline 7087.1 & 7086.9 & $\alpha_{\mathrm{s} 1}-\mathrm{CN}(\mathrm{f} 34-90) 8 \mathrm{P}$ & 0.2 & n.d. \\
\hline \multicolumn{5}{|c|}{$\alpha_{\mathrm{s} 2}-\mathrm{CN}$ derived CPP } \\
\hline 1493.6 & 1492.7 & $\alpha_{\mathrm{s} 2}-\mathrm{CN}(\mathrm{f} 139-150) 1 \mathrm{P}$ & 1.2 & n.d. \\
\hline 1617.5 & 1616.5 & $\alpha_{\mathrm{s} 2}-\mathrm{CN}(\mathrm{fl}-12) 3 \mathrm{P}$ & 2.0 & n.d. \\
\hline 1931.7 & 1930.8 & $\alpha_{\mathrm{s} 2}-\mathrm{CN}(\mathrm{fl}-15) 3 \mathrm{P}$ & 8.6 & n.d. \\
\hline 2007.9 & 2006.7 & $\alpha_{\mathrm{s} 2}-\mathrm{CN}(\mathrm{f} 7-21) 4 \mathrm{P}$ & 0.4 & n.d. \\
\hline 2356.2 & 2355.1 & $\alpha_{\mathrm{s} 2}-\mathrm{CN}(\mathrm{fl}-18) 4 \mathrm{P}$ & 20.8 & n.d. \\
\hline 2666.7 & 2665.4 & $\alpha_{\mathrm{s} 2}-\mathrm{CN}(\mathrm{f} 51-72) 4 \mathrm{P}$ & 2.3 & n.d. \\
\hline 2748.6 & 2747.5 & $\alpha_{\mathrm{s} 2}-\mathrm{CN}(\mathrm{f} 1-21) 4 \mathrm{P}^{*}$ & 3.0 & 26.9 \\
\hline 2876.8 & 2875.7 & $\alpha_{\mathrm{s} 2}-\mathrm{CN}(\mathrm{fl}-22) 4 \mathrm{P}$ & 1.8 & n.d. \\
\hline 3005.2 & 3004.8 & $\alpha_{\mathrm{s} 2}-\mathrm{CN}(\mathrm{f} 2-24) 4 \mathrm{P}$ & 0.4 & n.d. \\
\hline 3134.3 & 3133.0 & $\alpha_{\mathrm{s} 2}-\mathrm{CN}(\mathrm{fl}-24) 4 \mathrm{P}^{*}$ & 24.2 & 46.0 \\
\hline 3382.0 & 3381.1 & $\alpha_{\mathrm{s} 2}-\mathrm{CN}(\mathrm{f} 49-76) 4 \mathrm{P}$ & 8.4 & n.d. \\
\hline 3461.9 & 3461.1 & $\alpha_{\mathrm{s} 2}-\mathrm{CN}(\mathrm{f} 49-76) 5 \mathrm{P}$ & 1.4 & n.d. \\
\hline 3666.0 & 3665.9 & $\alpha_{\mathrm{s} 2}-\mathrm{CN}(\mathrm{f} 16-45) 2 \mathrm{P}$ & 0.9 & n.d. \\
\hline 4166.4 & 4165.3 & $\alpha_{\mathrm{s} 2}-\mathrm{CN}(\mathrm{f} 115-149) 3 \mathrm{P}^{*}$ & 0.6 & n.d. \\
\hline 4294.7 & 4293.5 & $\alpha_{\mathrm{s} 2}-\mathrm{CN}(\mathrm{f} 115-150) 3 \mathrm{P}^{*}$ & 0.6 & n.d. \\
\hline \multicolumn{5}{|c|}{$\beta$-CN derived CPP } \\
\hline 960.5 & 959.9 & $\beta-\mathrm{CN}(\mathrm{f} 30-36) 1 \mathrm{P}$ & 0.8 & n.d. \\
\hline 1462.5 & 1461.4 & $\beta-\mathrm{CN}(\mathrm{f} 17-27) 3 \mathrm{P}$ & 1.8 & n.d. \\
\hline 1511.6 & 1510.4 & $\beta-\mathrm{CN}(\mathrm{f} 17-28) 2 \mathrm{P}$ & 0.6 & n.d. \\
\hline 1515.5 & 1514.4 & $\beta-\mathrm{CN}(\mathrm{f} 15-25) 4 \mathrm{P}$ & 1.3 & n.d. \\
\hline 1591.4 & 1590.4 & $\beta-\mathrm{CN}(\mathrm{f} 17-28) 3 \mathrm{P}$ & 19.5 & n.d. \\
\hline 1628.9 & 1628.3 & $\beta-\mathrm{CN}(\mathrm{f} 15-26) 4 \mathrm{P}$ & 0.7 & n.d. \\
\hline 1645.4 & 1644.3 & $\beta-\mathrm{CN}(\mathrm{f} 14-25) 4 \mathrm{P}$ & 1.1 & n.d. \\
\hline 1743.8 & 1742.5 & $\beta-\mathrm{CN}(\mathrm{f} 15-27) 4 \mathrm{P}$ & 16.0 & n.d. \\
\hline 1791.4 & 1790.6 & $\beta-\mathrm{CN}(\mathrm{f} 15-28) 3 \mathrm{P}$ & 7.9 & n.d. \\
\hline 1871.6 & 1870.6 & $\beta-\mathrm{CN}(\mathrm{f} 15-28) 4 \mathrm{P}$ & 100.0 & n.d. \\
\hline 1999.8 & 1998.7 & $\beta-\mathrm{CN}(\mathrm{f} 14-28) 4 \mathrm{P}$ & 0.4 & n.d. \\
\hline 2240.4 & 2239.0 & $\beta-\mathrm{CN}(\mathrm{f} 8-25) 4 \mathrm{P}$ & 1.6 & n.d. \\
\hline 2709.4 & 2708.5 & $\beta-\mathrm{CN}(\mathrm{f} 7-28) 4 \mathrm{P}$ & 4.1 & n.d. \\
\hline 2967.4 & 2966.7 & $\beta-\mathrm{CN}(\mathrm{fl}-24) 4 \mathrm{P}$ & 0.2 & n.d. \\
\hline 3080.5 & 3079.9 & $\beta-\mathrm{CN}(\mathrm{f} 4-28) 4 \mathrm{P}$ & 0.6 & n.d. \\
\hline 3123.2 & 3122.9 & $\beta-\mathrm{CN}(\mathrm{fl}-25) 4 \mathrm{P}^{*}$ & n.d. & 5.8 \\
\hline 3351.6 & 3350.2 & $\beta-\mathrm{CN}(\mathrm{fl}-27) 4 \mathrm{P}$ & 3.2 & 14.8 \\
\hline 3479.9 & 3478.4 & $\beta-\mathrm{CN}(\mathrm{fl}-28) 4 \mathrm{P}^{*}$ & 70.1 & 100.0 \\
\hline 3607.8 & 3606.6 & $\beta-\mathrm{CN}(\mathrm{fl}-29) 4 \mathrm{P} *$ & 13.2 & 6.0 \\
\hline 3803.8 & 3802.4 & $-\mathrm{CN}(\mathrm{fl}-28) 4 \mathrm{P}+1$ lactose & 0.7 & n.d. \\
\hline 3849.3 & 3848.8 & $\beta-\mathrm{CN}(\mathrm{fl}-31) 4 \mathrm{P}$ & 0.1 & n.d. \\
\hline 3978.2 & 3977.0 & $\beta-\mathrm{CN}(\mathrm{fl}-32) 4 \mathrm{P}$ & n.d. & 0.5 \\
\hline \multicolumn{5}{|c|}{ к-CN derived CPP } \\
\hline 6229.8 & 6228.8 & к-CN (f106-163)1P & 0.3 & n.d. \\
\hline 6788.5 & 6787.5 & К-CN (f106-169)1P & 0.1 & n.d. \\
\hline
\end{tabular}

n.d. not detected; ${ }^{*}$ CPP detected in vitro because it was liberated by plasmin in raw milk and enriched on HA.

Table 5. List of HA-enriched CPP identified in commercial samples of yogurt and pasteurized milk. Relative intensity of each peak is reported. 
For example, $\beta$-CN (f1-28)4P, a peptide representing 100\% intensity (assumed as base peak) of the signals in MALDI spectra, was reduced by approximately $30 \%$; this loss was associated with the transformation of pasteurized milk into yogurt. One can deduce that the original peptide undergoes degradation even considering the higher number of formed $\mathrm{CN}$ peptides. In yogurt, $\beta-\mathrm{CN}$ (f1-28)4P, the most common CPP in pasteurized milk, was hydrolyzed into the peptide $\beta-\mathrm{CN}$ (f15-28)4P, which thus becomes the most abundant CPP.

$\beta-\mathrm{CN}(\mathrm{f} 1-29) 4 \mathrm{P}, \beta-\mathrm{CN}(\mathrm{f} 1-28) 4 \mathrm{P}, \beta-\mathrm{CN}(\mathrm{f} 1-25) 4 \mathrm{P}, \beta-\mathrm{CN}(\mathrm{f} 1-24) 4 \mathrm{P}, \alpha_{\mathrm{s} 2}-\mathrm{CN}(\mathrm{f} 1-24) 4 \mathrm{P}, \alpha_{\mathrm{s} 2}-\mathrm{CN}$ (f1-21)4P, resulting from the $\mathrm{CN}$ hydrolysis by plasmin and enriched on HA, were also found as C-terminally shortened peptides. During fermentation and storage, $\alpha_{\mathrm{s} 2}-\mathrm{CN}$ (f115150)3P and $\alpha_{\mathrm{s} 2}-\mathrm{CN}$ (f115-149)3P derived by plasmin action did not react further to produce shorter peptides, most likely because of the absence of proteolytic enzymes. In the yogurt fraction recovered by centrifugation, only five multi-phosphorylated $\alpha_{s 1}-\mathrm{CN}$ and two lowphosphorylated $\kappa-\mathrm{CN}$, $\kappa-\mathrm{CN}$ (f106-163)1P and $\kappa-\mathrm{CN}$ (f106-169)1P, were identified. Few CPP were less phosphorylated than the native peptides due to the presence of milk phosphatase, which was denatured in all pasteurized cheese-milks. The presence of lactosylated $\beta-\mathrm{CN}$ (f128)4P CPP was indicative of yogurt made with high-heat treated or milk fortified with milk protein powder [102]. Proteolysis of milk proteins in model yogurt systems has shown a similar set of primary CPP (Table 5). Therefore, the question is raised how CPP, derived from the enzymatic hydrolysis of yogurt $\mathrm{CN}$ are digested and absorbed in adult humans. For this reason, it is important to know the gastrointestinal resistance of CPP if used as a functional ingredient for fruit beverages. In the various stages of human digestion, a large quantity of CPP is produced in the stomach by partial hydrolysis of $\mathrm{CN}$ through pepsin action and in the small intestine by trypsin; these peptides are successively refined by endoproteases/exopeptidases. Although analysis of the intestinal contents of milk and yogurt ingestion has revealed the presence of CPP [60], their further resistance to gastrointestinal enzymes is poorly documented. Fragment $\beta-\mathrm{CN}$ (f1-24)4P has been previously identified in the lumen contents of rats after $60 \mathrm{~min}$ of digestion as a $\beta-\mathrm{CN}$ (f1$25) 4 \mathrm{P}$ derived peptide [106]. Moreover, after yogurt ingestion, $\beta-\mathrm{CN}$ (f1-32)4P CPP was released in the human stomach [60] and $\beta-\mathrm{CN}$ (f1-31)4P was found in a yogurt sample. The fragment $\beta$-CN (f1-28)4P constitutes a clear example of the multi-functionality of milkderived peptides because some regions in the primary structure of caseins contain overlapping peptide sequences that exert different biological effects, in this case both mineral binding and immunostimulatory action [107]. Even with the difference in the peptide pattern, it is evident that CPP binding iron (or other metal ions) remains soluble in the digestive tract, where they escape further enzyme digestion [106]. The authors have studied in depth the simulated digestion of CPP from peptide precursors. These studies greatly benefit from the knowledge of enzyme specificities and degradation mechanisms. CPase and chymotryptic activity of pancreatin exhibits broad specificity, cleaving bonds on the carboxyl side of several amino acid residues of CPP. The latter, which are in the mass range 960-7087 Da (Table 5), are good candidates for intestinal absorption and for playing a possible physiological role in mineral bioavailability. However, there are conflicting results on the lack of $\alpha_{\mathrm{s} 1}-\mathrm{CN}$ (f43-52)2P and $\alpha_{\mathrm{s} 2}-\mathrm{CN}$ (f1-19)4P identified by other authors after $\mathrm{CN}$ hydrolysis with pancreatin, an enzyme used during the intestinal step of simulated 
physiological digestion [108]. Generally, the physiological effects of CPP may not always be extended to precursor peptides, although they are structurally similar. There are not enough data concerning the effects of CPP addition to probiotic acid fermented milks. However, probiotic bacteria such as Lactobacillus acidophilus and Bifidobacterium spp., selected because of their beneficial action, which they may manifest on the health of the consumer, grow slowly in milk because of the lack of the proteolytic activity [109]. For this reason, and also to reduce the fermentation time, probiotic yogurt is manufactured by yogurt bacteria (Streptococcus thermophilus and Lactobacillus delbrueckii ssp. bulgaricus) with the addition of probiotic culture. In parallel, non-digestible food ingredients, i.e., "prebiotics", resist digestion in the small intestine and reach the colon, where they act as a growth factor for Bifidobacterium species and are metabolized into short chain fatty acids by a limited number of the microorganisms also comprising the colonic microflora. Prebiotics are principally oligosaccharides (fructo-oligosaccharides, inulins, isomalto-oligosaccharides, lactilol, lactosucrose, lactulose, pyrodextrins, soy oligosaccharides, transgalacto-oligosaccharides, and xylo-oligosaccharides) that stimulate bifidobacteria growth. In probiotic yogurt containing inulin as a prebiotic, the number of bioactive peptides increased, which means that elevation in the proteolytic activity has a synergistic effect with probiotic counts of yogurt cultures. Therefore, the most proteolytic strains of St. thermophilus and Lb. delbrueckii subsp. bulgaricus, spp. enhance the growth of Lb. acidophilus and Bifidobacterium. In our studies, the overall opiate activity of the bio-yogurt preparation containing $\mathrm{Lb}$. acidophilus and Bifidobacterium spp. and inulin as a prebiotic was approximately twice that typical of traditional yogurt. In addition, the above yogurt preparation contained a variety of opioid agonistic and antagonistic, immunomodulation, anti-thrombotic, ACE-inhibitor, and antimicrobial activities. Traditional and probiotic yogurt both possess a characteristic soluble fraction composed by peptides exhibiting biological activity, amongst others. This fraction was found to include CPP, $\beta$-casomorphins and antithrombotic peptide precursors that did not differ greatly from one another. In a study comparing the proteolytic, amino-, di-, triand endopeptidase activity of nine strains of St. thermophilus, six strains of Lb. delbrueckii, fourteen strains of $\mathrm{Lb}$. acidophilus and thirteen strains of Bifidobacterium spp., aminopeptidase activity was detected for all bacterial strains - traditional yogurt strains and probiotic bifidobacteria - both at the extracellular and intracellular levels. High dipeptidase activity was demonstrated by all bacterial strains for Lb. delbrueckii ssp. bulgaricus, Lb. acidophilus, and Bifidobacterium spp., whereas St. thermophilus had greater dipeptidase activity at the extracellular level.

\subsection{CPP in a few cheese varieties}

Whole milk contains a variety of endogenous plasmin-mediated $\mathrm{CN}$ peptides. In addition, CPP were released following cell lysis and release of intracellular LAB enzymes. This phenomenon was observed especially at the end of ripening in long-ripened cheeses, such as Comté [110], Grana Padano [111], Parmigiano-Reggiano and semi-hard Herrgard cheese [112]. In Grana Padano cheese, 45 CPP were identified, of which 24 originated from $\beta$-casein,

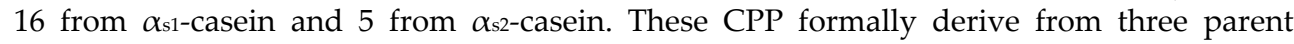
peptides, namely $\beta-\mathrm{CN}$ (f7-28)4P, $\alpha_{\mathrm{s} 1}-\mathrm{CN}$ (f61-79)4P and $\alpha_{\mathrm{s} 2}-\mathrm{CN}$ (f7-21)4P [111]. By 
comparing CPP of Grana Padano and Herrgard cheese, it was clear that CPP were all progressively shortened and dephosphorylated during ripening. CPP were very resistant to enzymatic degradation, especially when SerP residue was at the $\mathrm{N}$-terminal end. The number of CPP identified according to the different procedures was comparable for Grana Padano [111] and Herrgard cheese [112]. In both the cheeses, CPP were progressively shortened and dephosphorylated during ripening, with both cheeses constituting heterogeneous mixtures of peptides phosphorylated at various sites sharing $\mathrm{N}$ - and $\mathrm{C}$ terminally truncated CPP. However, some peptides proved very resistant to enzymatic degradation, especially when SerP residue was present at the N-terminal end of CPP [111]. The only SerP residue located at the N-terminus of CPP was subjected to dephosphorylation, exposing the dephosphorylated residue to aminopeptidase action. A heterogeneous CPP pattern also differentiated the cheese samples within a given form because of the phosphatase gradient amongst peripheral and central parts of the Grana Padano cheese form $\left(310^{5} \mathrm{vs} .310^{2}\right)$. This is due to heat sensitivity in the temperature range 57 and $62{ }^{\circ} \mathrm{C}$ and the acid $\mathrm{pH}$ at which these enzymes are denatured. These data explain the discrepancy in the amount of serine, which varied by as much as $50 \%$ of SerP from the periphery towards the center of the cheese form [113]. In contrast, the CPP fraction of Herrgard cheese was more uniform, with the two cheese varieties sharing active plasmin and amino-peptidases from lactic acid bacteria. Because milk pasteurization denatures alkaline phosphatase while it activates plasmin [114], proteolysis in the above cheese is plasmin-dependent. It is therefore likely that CPP of pasteurized milk cheeses are intrinsically more stable than raw milk cheeses [111]. CPP in artisanal PDO ovine Fiore Sardo cheese have been previously reported [115]. Patterns of CPP similar to that observed for bovine cheese indicated that mechanisms of formation and degradation of CPP were similar regardless of the milk species and cheese variety. The dephosphorylation mechanism in Fiore Sardo was different from that found in Grana Padano cheese, most likely because of the use of different rennet types. In PDO Fiore Sardo cheese, no apparent difference in susceptibility to dephosphorylation was found amongst the differently located SerP peptide residues. This resulted in the simultaneous occurrence of partly dephosphorylated peptides, either internally or externally. CPP enrichment by HA, for example of $\mathrm{pH} 4.6$ soluble fractions of hard Parmigiano Reggiano (PR) (30-mo-old), semi-hard, pasta filata Provolone del Monaco (PM) (6-mo-old), semi-cooked Asiago d'Allevo (AA) (3-mo-old) and moldripened cheese Gorgonzola (GR) (2-mo-old) cheese, has allowed the identification of CPP in high number (Figure 5) which may explain the broad-specificity of the cheese enzymes involved in CN proteolysis. Some CPP were derived from the Lys-X or Arg-X cleavage by

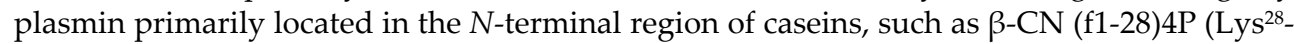

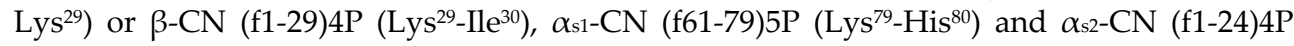
$\left(\mathrm{Lys}^{24}-\mathrm{Asn}^{25}\right)$. The native plasmin-derived CPP were then further hydrolyzed by cheese aminopeptidases and CPase into shorter peptides.

It is likely that ingested cheese carries a concentrated $\mathrm{pH} 4.6$ soluble CPP fraction and a variable number of CPP according to the cheese variety. Above all, the presence and integrity of plasmin-mediated products of $\mathrm{CN}$ is a function of the milk, whether raw or pasteurized. Pasteurization reduces the milk plasmin activity only by $\sim 15$ percent, whereas plasmin activity increases during milk storage. UHT does not inactivate the plasmin in milk, 


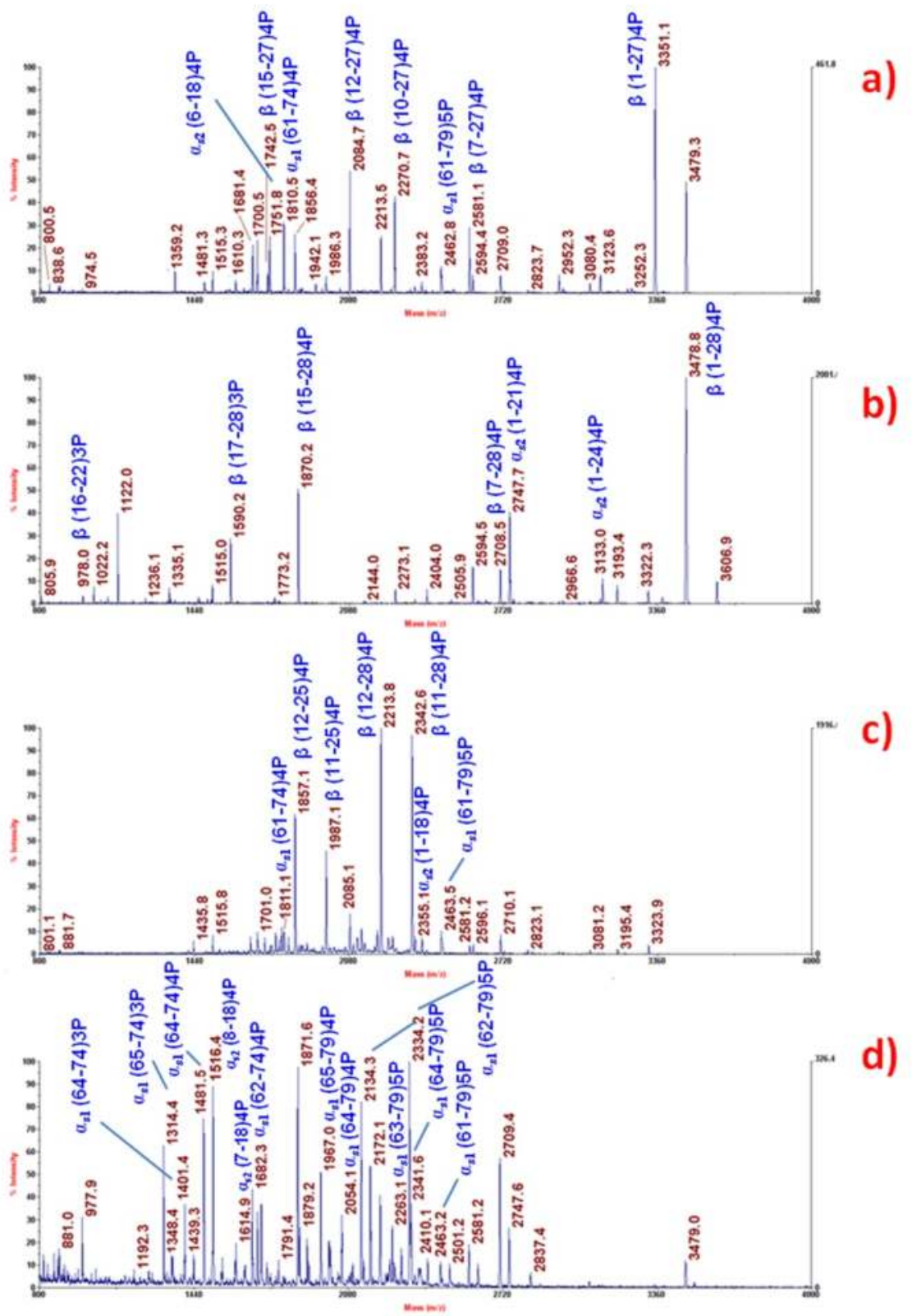

Figure 5. The MALDI spectra of CPP isolated by the addition of HA to $\mathrm{pH} 4.6$ soluble fractions of Gorgonzola (a), Asiago (b), Provolone del Monaco (c), and Parmigiano Reggiano (d) cheeses. The inset magnifies the $\mathrm{m} / \mathrm{z}$ values in the lower molecular mass peptide range $0.8-4 \mathrm{kDa}$. 
and proteolytic activity will continue to damage milk. Heat treatments modify the peptide profile by increasing the content of larger peptides. The $\mathrm{CN}$ breakdown occurring during the ripening of PR cheese proceeded more slowly in PM cheese.. This means that eating PR cheese increases the quota of the co-ingested mineral bound CPP. In contrast, GR cheese show a different CPP level such as that of $\beta-\mathrm{CN}$ (f1-27)4P (3350.2 Da), resulting the most abundant $\mathrm{CPP}$, when compared with hard cheeses (Figure 5a and 6); $\beta$-CN (f1-27)4P was further hydrolyzed into the shorter $\beta-\mathrm{CN}$ (f7-27)4P (2580.4 Da), $\beta$-CN (f10-27)4P (2270.0 Da), $\beta$ - CN (f12-27)4P (2083.8 Da) and $\beta$-CN (f15-27)4 (1742.4 Da). The most abundant CPP in all three cheeses derived from the peptide $\beta-\mathrm{CN}$ (f1-28)4P, but long-ripened PR cheese was dissimilar from the other cheeses in its content of $\alpha_{\mathrm{s} 1}-\mathrm{CN}$ (f62-79)5P (2332.9 Da) (Figure 5d and 6).

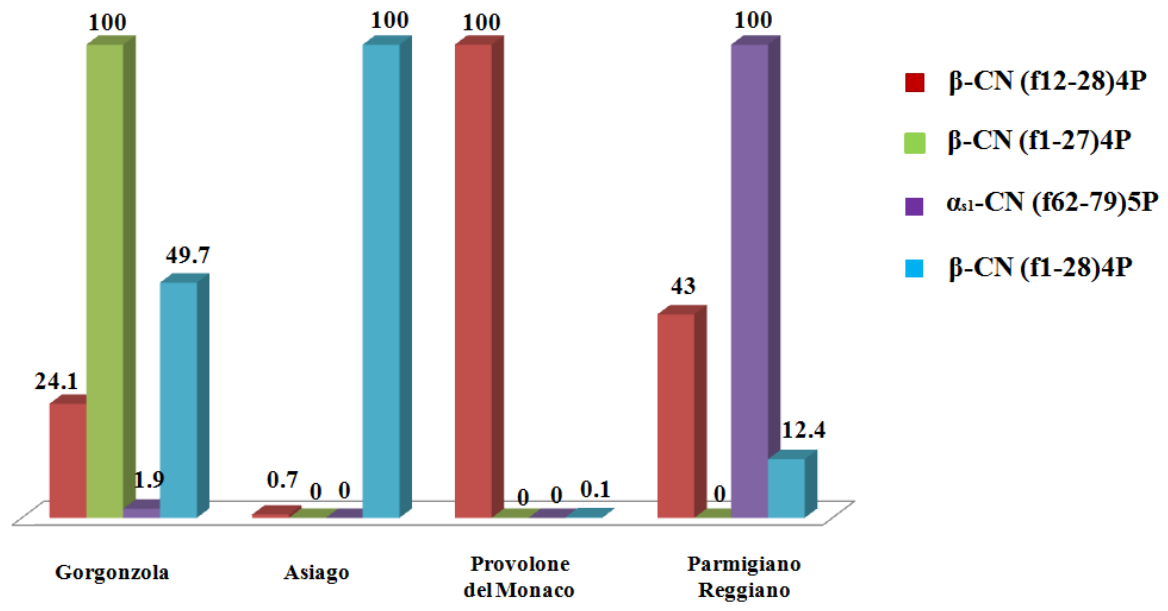

Figure 6. Histogram representation of CPP at $100 \%$ relative intensity and their performance in four cheeses.

$\beta-\mathrm{CN}$ (f1-28)4P (3478.4 Da) in AA cheese was the most abundant signal of the MALDI spectra and it was partially hydrolyzed into the shorter peptides $\beta$-CN (f7-28)4P (2708.5 Da), $\beta-\mathrm{CN}$ (f15-28)4P (1869.7 Da) and $\beta$-CN (f17-28)3P (1589.6 Da) (Figure 5b and 6). Considering exclusively the CPP molecular mass in the 3-3.5 $\mathrm{kDa}$ range of AA and GR cheese, the intensity of a high number of peptides transformed into a number of progressively lower molecular weight CPP, with accompanying liberation of peptides (Figure 5). The most common group of CPP occurred in the mass range of 1.7-2.9, reaching the maximum intensity for $\beta-\mathrm{CN}$ (f12-28)4P (2212.0 Da) in PM and $\alpha_{s 1-C N}(\mathrm{f} 62-79) 5 \mathrm{P}$ (2332.9 Da) in PR cheese (Figure $5 \mathrm{c}-\mathrm{d}$ and 6). The presence of $\beta-\mathrm{CN}$ (f16-22)3P (977.7 Da) was discovered in both AA and PR cheeses and was not detected in the PM and GR cheeses (Figure 5). Our results show that longer plasmin-mediated peptides degraded into shorter CPP. These peptides became more evident when the chymosin retained in the cheese was largely inactivated by cooking the curd at high temperatures $\left(\sim 55^{\circ} \mathrm{C}\right)$. The hydrolysis of $\mathrm{CN}$ by 
chymosin was covered by that of plasmin, which became the principal proteolytic enzyme in the cheese. This phenomenon is particularly evident in PM raw milk cheese for which the plasmin-mediated $\beta-\mathrm{CN}$ (f1-28)4P peptide, representing $\sim 0.1 \%$ of the $\mathrm{CPP}$, was almost completely hydrolyzed into the shorter peptides $\beta-\mathrm{CN}$ (f11-28)4P (2341.1 Da), $\beta$-CN (f1228)4P (2212.0 Da), $\beta$-CN (f11-25)4P (1985.7 Da) and $\beta$-CN (f12-25)4P (1856.6 Da) (Figure 5c). When comparing the PR and PM cheese, the former had a high extent of $\beta$-CN (f1-28)4P as judged by the higher levels of the peptide. This demonstrates that CPP of PR cheese are progressively transformed into a number of lower-molecular-weight peptides. In contrast, the quasi-total absence in the PM cheese of $\beta-\mathrm{CN}$ (f1-28)4P and relatively few of the various sizes $\beta$-CN-derived CPP (Figure 6) could be the effect of the enzyme decline from the optimum level of activity to zero enzyme activity.

$\alpha_{\mathrm{s} 1-\mathrm{CN}} \mathrm{CPP}$ originated for the greater parts from the internal regions of the amino acid sequence, namely $\alpha$ s1-CN (f61-79)5P and $\alpha$ s1-CN (f33-60)3P.

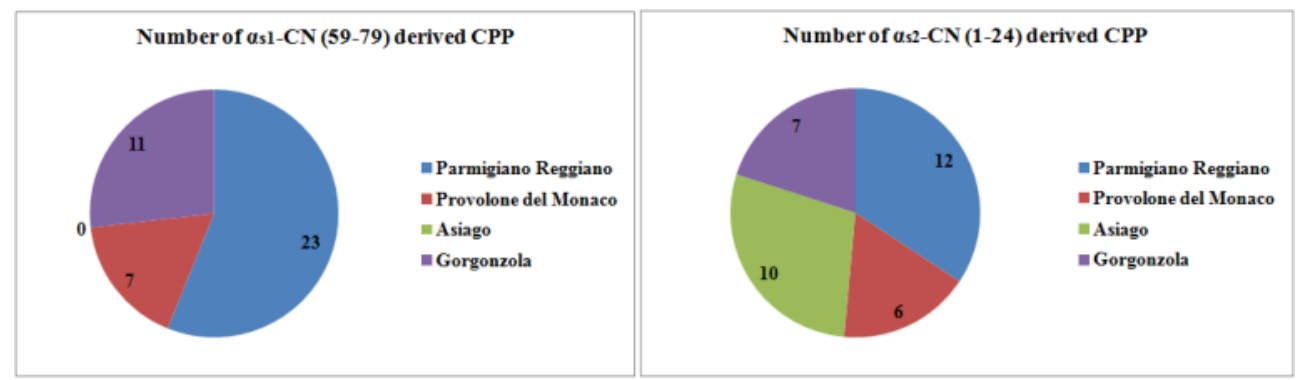

Figure 7. The number of CPP derived from $\alpha_{\mathrm{s} 1}-\mathrm{CN}$ (f59-79)5P and $\alpha_{\mathrm{s2} 2}-\mathrm{CN}$ (f1-24)4P in Parmigiano Reggiano, Provolone del Monaco, Asiago and Gorgonzola cheeses.

In PR cheese, 23 casein-derived CPP were found to derive from the internal region of $\alpha_{\mathrm{s} 1}$ $\mathrm{CN}$, i.e., $\alpha_{s 1}-\mathrm{CN}$ (f59-79)5P, whereas they were not detected in AA (Figure 7).

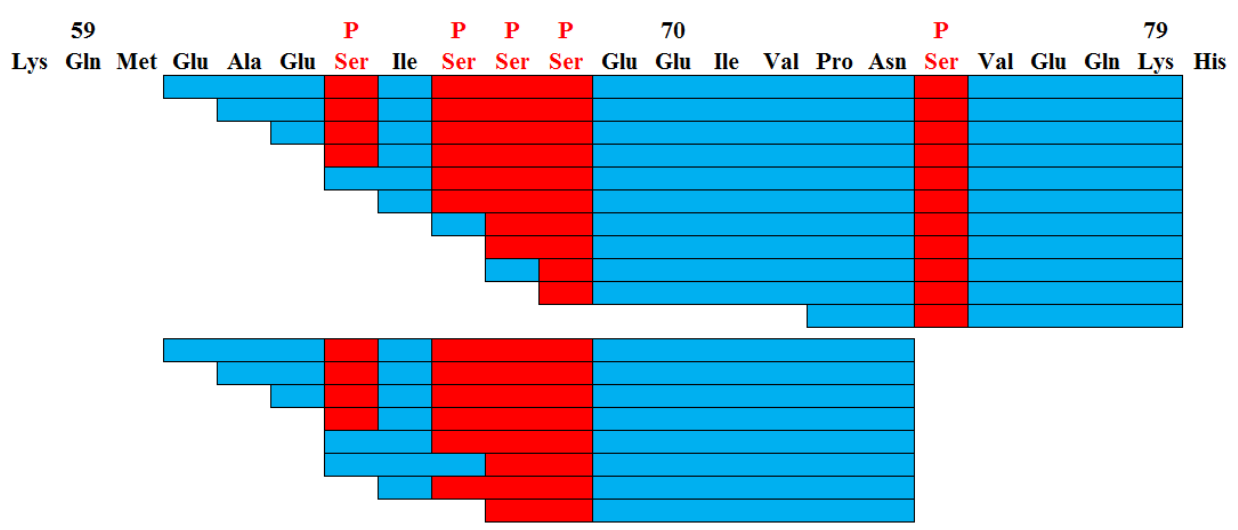

Figure 8. Amino acid sequence of the $\alpha_{\mathrm{s} 1}-\mathrm{CN}$ (f59-79) $4 \mathrm{P}$ peptide and the CPP identified in PR cheese. Phosphoserine residues are indicated by red boxes. 
The profile of the CPP depicts the mechanisms of both the proteolysis and dephosphorylation in a long ripened cheese. Peptide $\alpha_{\mathrm{s} 1}-\mathrm{CN}$ (f61-79)5P, most likely arising from the parent peptide $\alpha_{s 1}-\mathrm{CN}$ (f1-79)7P through cleavage at $\mathrm{Met}^{60}-\mathrm{Glu}^{61}$, was dephosphorylated and concurrently hydrolyzed into shorter peptides. Alkaline and/or acid phosphatases acting on SerP residue dephosphorylated CPP. N-terminal Ser was then exposed to aminopeptidase and released as a free amino acid. Bacterial CPase or exopeptidase such as cathepsin D/chymosin release $\alpha_{\mathrm{s} 1}-\mathrm{CN}$ (f61-74)4P and other derived $\mathrm{CPP}$ through cleavage at $\mathrm{Asn}^{74}-\mathrm{SerP}^{75}$ (Figure 8). In PR aged 30 months, $\alpha_{\mathrm{s} 1}-\mathrm{CN}$ (f61-79)5P $(2462.1 \mathrm{Da}), \alpha_{\mathrm{s} 1}-\mathrm{CN}(\mathrm{f} 62-79) 5 \mathrm{P}(2332.9 \mathrm{Da}), \alpha_{\mathrm{s} 1}-\mathrm{CN}(\mathrm{f} 63-79) 5 \mathrm{P}$ (2261.9 Da), $\alpha_{\mathrm{s} 1}-\mathrm{CN}(\mathrm{f} 64-79) 5 \mathrm{P}$ $(2132.8 \mathrm{Da}), \alpha_{\mathrm{s} 1}-\mathrm{CN}(\mathrm{f} 64-79) 4 \mathrm{P}(2052.8 \mathrm{Da}), \alpha_{\mathrm{s} 1}-\mathrm{CN}$ (f65-79)4P (1965.7 Da), $\alpha_{\mathrm{s} 1}-\mathrm{CN}$ (f62-74)4P (1681.3 Da), $\alpha_{\mathrm{s} 1}-\mathrm{CN}(\mathrm{f} 64-74) 4 \mathrm{P}(1481.2 \mathrm{Da}), \alpha_{\mathrm{s} 1}-\mathrm{CN}(\mathrm{f} 64-74) 3 \mathrm{P}(1401.2 \mathrm{Da})$ and $\alpha_{\mathrm{s} 1}-\mathrm{CN}$ (f6574)3P (1314.1 Da) were the dominant CPP (Figure 5d and 8). Indeed, only 7 CPP for PM cheese and 11 CPP for GR were derived from $\alpha_{s 1}-\mathrm{CN}$ (f59-79)5P, namely $\alpha_{\mathrm{s} 1}-\mathrm{CN}$ (f61-79)5P (2462.1 Da) and $\alpha_{\mathrm{s} 1}-\mathrm{CN}(\mathrm{f} 61-74) 4 \mathrm{P}(1810.5 \mathrm{Da})$ (Figure 5a and $\mathrm{c}$ and 7). Considering the $\alpha_{\mathrm{s} 2}-$ $\mathrm{CN}$ peptide, the $\alpha_{\mathrm{s} 2}-\mathrm{CN}$ (f1-24)4P CPP were similar in number but significantly different in the case of the four cheese varieties (Figure 6). The dominant $\alpha_{\mathrm{s} 2} \mathrm{CN}$-derived CPP were $\alpha_{\mathrm{s} 2}$ $\mathrm{CN}(\mathrm{f} 1-24) 4 \mathrm{P}(3132.9 \mathrm{Da})$ and $\alpha_{\mathrm{s} 2}-\mathrm{CN}(\mathrm{f} 1-21) 4 \mathrm{P}(2747.6 \mathrm{Da})$ in AA cheese (Figure $\left.5 \mathrm{~b}\right)$. The most abundant $\alpha_{\mathrm{s} 2}-\mathrm{CN}$-derived CPP were $\alpha_{\mathrm{s} 2}-\mathrm{CN}$ (f1-18)4P (2355.1 Da) for PM and $\alpha_{\mathrm{s} 2}-\mathrm{CN}$ (f6-18)4P (1751.4 Da), a shortened form of the primary CPP $\alpha_{\mathrm{s} 2}-\mathrm{CN}$ (f1-18)4P, for GR cheese (Figure 5a and c). $\alpha_{\mathrm{s} 2}-\mathrm{CN}$ (f7-18)4P (1614.3 Da) and $\alpha_{\mathrm{s} 2}-\mathrm{CN}$ (f8-18)4P (1515.1 Da) characteristically accumulated in $\mathrm{PR}$ cheese (Figure $5 \mathrm{~d}$ ). Similar and discrete phosphorylated CPP derived species for $\alpha_{\mathrm{s} 2}-\mathrm{CN}$ (f1-24) (3P and 4P) and $\beta-\mathrm{CN}$ (f1-28) (3P and $4 \mathrm{P})$ occurred in all cheeses. For the other casein fractions, primary CPP are fully phosphorylated, such as $\alpha_{\mathrm{s} 1}-\mathrm{CN}$ (f61-79)5P, whereas the derived peptides show a level of phosphorylation less than native form as observed in PM and GR. A higher dephosphorylation level characterized the CPP profile of PR cheese (Figure 8). The different profile of CPP could derive from the different length of ripening and from the cheese variety.

\section{CPP in ovine cheeses}

Cheeses that contain CPP are also manufactured from ovine milk. Proteolytic enzymes in Pecorino cheese originate from chymosin, pepsin and other clotting preparations such as paste rennet. These enzymatic activities are complemented by those secreted by the vegetative spores of Penicillium roqueforti during the maturation of blue-veined cheeses. The CPP patterns of Pecorino and Roquefort cheese have been characterized and main components identified. The sequence alignment of the CPP released throughout the hydrolysis of the $\beta-\mathrm{CN}$ (f1-28)4P in Pecorino and Roquefort cheeses are compared in Figure 9.

In PR cheese of different ages, the released CPP were progressively degraded at C- and Nterminal ends. CPases work from the C-terminal end and aminopeptidases from the $\mathrm{N}$ terminal end, both removing the terminal amino acid residues incrementally. LAB does not produce CPases; thus, the ability to liberate the carboxyterminal amino acid and peptides is typical of the mold. The N-terminal amino acid seemed to be released faster than the C- 
terminal residues because of the lower activity of CPases. There are negligible differences in the CPP level of different cheese lots primarily because of the action of the enzymes from $P$. roqueforti after its sporulation in blue-veined cheese. More long-chain $\mathrm{CPP} \beta-\mathrm{CN}$, such as $\beta$ $\mathrm{CN}$ (f1-28)5P-4P, $\beta-\mathrm{CN}$ (f1-27)5P-4P and $\beta-\mathrm{CN}$ (f1-24)5P-4P, were detected in Pecorino cheese, whereas $\beta-\mathrm{CN}$ (f7-28)5P-4P and $\beta-\mathrm{CN}$ (f7-27)5P-4P resulted from the longer CPP in Roquefort cheese (Figure 9). In these cheese varieties, both $\alpha_{s 1-}$ and $\beta$-CN have been described as completely hydrolyzed at the end of ripening. This contradicts other findings indicating $\sim 50 \% \mathrm{CN}$ hydrolysis. Plasmin, NSLAB, and Lactobacilli contaminating flora proteinases are mainly responsible for extensive proteolysis in Parmigiano-Reggiano cheese, which is ripened for $\sim 24$ months at $\sim 18-20{ }^{\circ} \mathrm{C}$ [116]. Here, chymosin is denatured by the high cooking temperature used during the manufacture of cheese. Molds develop at approximately 2 to 5 weeks of ripening, concurrently degrading $\mathrm{CN}$ into peptides of various sizes [117]. A similar mechanism for $\beta-\mathrm{CN}$-derived CPP was found in Grana Padano cheese. Ser was proteolytically cleaved by aminopeptidases, and SerP hindered cleavage by the latter and continued its action after dephosphorylatation of SerP.

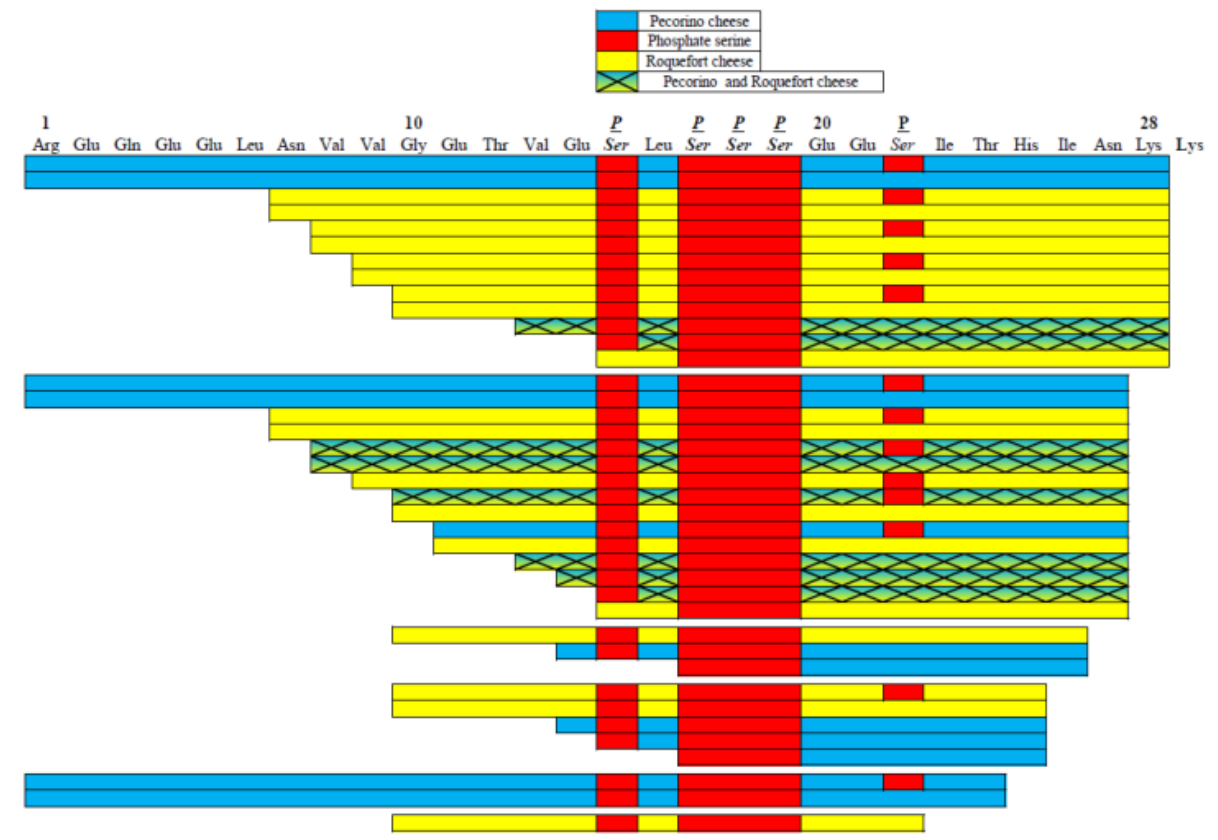

Figure 9. Amino acid sequence of the $\beta-\mathrm{CN}$ (f1-28)4P peptide and the CPP identified in Pecorino (blue line) and Roquefort (yellow line) cheeses. CPP common to the two cheeses are indicated by crosses, and phosphoserine residues are indicated by red boxes.

\section{Anticariogenic effect of CPP in yogurt and cheese}

Due to proteolytic activity, a great number of CPP are formed in raw milk cheese. In contrast, the enzymatic digestion of proteins to peptides can be reduced by milk 
pasteurization. Notwithstanding this, yogurt remains a consistent source of bioavailable CPP even if milk is heated to high temperatures $\left(90^{\circ} \mathrm{C}, 30 \mathrm{~min}\right)$ to create an inoculation medium in which the bacteria can grow and produce lactic acid. LAB provide plenty of CPP in the form of soluble complexes with $\mathrm{Ca}^{2+}$ that are effective in avoiding the lifethreatening calcium phosphate precipitation, enhancing the intestinal absorption of minerals and retention in the human body [34,118]. The mineral-binding power of CPP also depends on the number of binding sites and their relative accessibility [119]. Dairy products such as cheese and yogurt are both rich in multi-phosphorylated peptides capable of interacting with colloidal calcium phosphate to manifest anticariogenic properties in human and animal [120-121,13]. The mechanism of anticariogenicity might be due to a direct chemical effect of casein and calcium phosphate components [122]. Tooth enamel is a polymeric substance consisting of crystalline calcium phosphate, embedded in a protein matrix. Thus, CPP can significantly enhance localization of ACP at the tooth surface, inhibiting enamel demineralization and promoting remineralization. In the development of teeth and bone, CPP act as hydroxyapatite nucleator and control the growth of the crystals, resulting in unique crystal morphology. A new calcium phosphate remineralization technology has been recently developed based on the complex CPP-ACP [Recaldent ${ }^{\text {TM }}$ CASRN691364-49-5] [66]. This preparation is claimed to stabilize calcium and phosphate ions in high concentrations by binding ACP to pellicle and plaque of the tooth surface. Moreover, CPP-ACP inhibited the adhesion of Streptococcus mutans to the tooth surface producing a copious reservoir of bioavailable calcium ions [67]. Cheese and yogurt CPP have the ability to stabilize calcium phosphate in solution, forming small CPP-ACP nanocomplexes. The calcium-binding ability of CPP has been applied by clinical dentists to show that CPP stabilize high concentrations of calcium, phosphate, and fluoride ions on the tooth surface by binding them to pellicle and plaque $[66,123]$. In dental plaque, CPP-ACP binds onto the surface components of the intercellular plaque matrix. Incorporation of CPP-ACP into the plaque will increase the calcium and phosphate content by forming a stable supersaturated solution of calcium phosphate. Thus, the availability of calcium in plaque provides a natural anticaries protective effect, either by suppression of demineralization promoted by fermentative acids in mouth, through an increased remineralization by binding calcium ions to teeth enamel, or possibly a combination of both. An inverse relation between plaque calcium and caries incidence has been evidenced [124-125]. Reynolds (1997) [126] has demonstrated that CPP-ACP can actually remineralize subsurface lesions in human enamel, and this is indeed the basis of one claim of his patent [127]. The diffusion of available CPP-ACP in the mouth is controlled by two main factors: i) the molecular weight of the diffusing species, the square of which is inversely proportional to the diffusion coefficient; and ii) the binding characteristics of the diffusing species, which dictate how much CPP-ACP is free to diffuse at a given time [128]. At neutral $\mathrm{pH}$, calcium diffusion is limited by the quantity of bound calcium, reducing the effective diffusion coefficient (De) and creating a measurable restricted effective diffusion coefficient $(r D e)$, where $r D e=D e /(R+1)$ and $R$ is the ratio of bound to free calcium. A large number of potential binding sites for calcium can have significant effects on the calcium diffusion coefficient; this effect is maintained at 
low $\mathrm{pH}$, although overall diffusion is slightly faster [129-130]. Conversely, one may infer that ACP may also bind to dental plaque and tooth enamel, thus having beneficial effects on teeth remineralization [67]. In addition, SerP residues of the CCP-HA complex are exposed to intestinal alkaline phosphatase, which favors metal ion bioavailability by releasing inorganic phosphate. Milk, ice cream, and cheese have been observed to lower the incidence of dental caries in rats [131]. Elderly people that eat cheese several times per week had a lower incidence of root surface caries development [132]. CPP of yogurt have been observed to have an inhibitory effect on demineralization and are able to promote remineralization of dental enamel [133]. Moreover, anticariogenic activity has also been reported for egg phosphopeptides (viz. phosvitin and phosphophorin) [134-135]. The heating process affects the bioavailability of CPP; for example, milk sterilization can induce dephosphorylation of phosphoseryl residues and dehydroalanine residue formation [136].

\section{CPP as nutraceutical ingredients in functional foods}

\subsection{Examples of commercial CPP preparation}

Some commercial products have been developed containing moderately hydrolyzed milk proteins as the sole protein source. Hypoallergenic formulas are based on partially or extensively hydrolyzed proteins. Both formulae are better tolerated by small premature infants than native cow milk protein. Ultrafiltered micellar casein and microfiltered whey protein concentrate are known to slow down the digestive process. Typical composition data of commercial phosphopeptide preparations $(\mathrm{m} / \mathrm{m})$ include $91.3 \%$ (TN x 6.47) or 94.8 (dry basis) protein, 16.0\% CPP, and 6.0\% free amino acids. Compared with the expected CPP composition, the commercial preparation contained $\sim 5 \%$ undigested protein, $\sim 30 \%$ peptides in the intermediate molecular mass 5000-20000 Da range, and $\sim 48 \%$ of molecular mass in the 500-5000 Da range (Tatua, New Zealand). The preparation is generally very complex and dependent on the procedure used to perform casein hydrolysis. Therefore, commercial products can be considered to be an enriched-CCP preparation containing $16 \%$ CPP without specification of the peptide size and phosphorylation degree. Preliminary analysis performed by MALDI-TOF analysis indicated that the signal in the mass spectra originated exclusively from the $\beta-\mathrm{CN}$ digestion. The intensity of non-CPP such as $\beta-\mathrm{CN}$ (f191-209), $\beta$-CN (f184-209), $\beta$-CN (f177-209) and $\beta-\mathrm{CN}$ (f170-209) was sufficiently high to obscure other $\mathrm{CN}$ peptides (MALDI spectrum not shown). As reported above, a number of available techniques allow the separation of CPP and non-CPP. To reduce the large dynamic range of non-CPP, HA was used for CPP enrichment $[90,94,102]$. CPP included multiply phosphorylated peptides (up to 4 phosphorylation residues). CPP $\beta$-CN (f1$28) 4 \mathrm{P}$ and $3 \mathrm{P}, \beta-\mathrm{CN}$ (f1-25) $4 \mathrm{P}, 3 \mathrm{P}$ and $2 \mathrm{P}$ and $\beta-\mathrm{CN}$ (f2-25) $4 \mathrm{P}, 3 \mathrm{P}$ and $2 \mathrm{P}$ were found and may be indicative of the progressive CPP dephosphorylation (MALDI spectrum not shown). Interestingly, in addition to $\beta-\mathrm{CN}$, the commercial CPP (Tatua, NZ) also displayed $\alpha_{\mathrm{s} 1}$ - or $\alpha_{\mathrm{s} 2}-\mathrm{CN}$-derived CPP, invisible or weakly visible before the sample was treated with HA (Table 6). 
Finally, a method for reducing the complexity of peptide mixtures was the separation of non-CPP and CPP by trapping CPP on HA under neutral conditions. This could be the principle for an industrially based production of CPP.

\begin{tabular}{|c|c|c|c|c|c|c|}
\hline \multirow{2}{*}{$\begin{array}{l}\text { Parent } \\
\text { Protein }\end{array}$} & \multicolumn{2}{|c|}{ Molecular Mass (Da) } & \multirow{2}{*}{ Start } & \multirow{2}{*}{ End } & \multirow{2}{*}{ Peptide Sequence } & \multirow{2}{*}{$\begin{array}{c}\text { Peptide } \\
\text { Modifications }\end{array}$} \\
\hline & Measured & Theoretical & & & & \\
\hline \multirow[t]{18}{*}{$\alpha_{\mathrm{s} 1}-\mathrm{CN}$} & 1138.4 & 1138.4 & 115 & -123 & (N)SAEERLHSM(K) & $1 \mathrm{P}$ \\
\hline & 1526.7 & 1526.7 & 35 & -47 & (K)EKVNELSKDIGSE(S) & $1 \mathrm{P}$ \\
\hline & 1831.9 & 1831.8 & 75 & -89 & (N)S VEQKHIQKEDVPSE(R) & $1 \mathrm{P}$ \\
\hline & 1859.9 & 1859.9 & 75 & -89 & (N)S VEKHIQKEDVPSER(Y)* & $1 \mathrm{P}$ \\
\hline & 1926.5 & 1926.7 & 43 & -58 & (K)DIGSESTEDQAMEDIK(Q) & $2 \mathrm{P}$ \\
\hline & 1950.9 & 1950.9 & 104 & -119 & (K)YKVPQLEIVPNS AEER(L) & $1 \mathrm{P}$ \\
\hline & 1988.0 & 1987.9 & 75 & - 90 & (N)S VEQKHIQKEDVPSER(Y) & $1 \mathrm{P}$ \\
\hline & 2054.7 & 2054.7 & 43 & -59 & (K)DIGS ESTEDQAMEDIKQ(M) & $2 \mathrm{P}$ \\
\hline & 2185.8 & 2185.8 & 43 & -60 & (K)DIGSESTEDQAMEDIKQM(E) & $2 \mathrm{P}$ \\
\hline & 2400.9 & 2400.9 & 41 & - 60 & (L)SKDIGSES TEDQAMEDIKQM(E) & $2 \mathrm{P}$ \\
\hline & 2597.0 & 2597.0 & 37 & -58 & (K)VNELSKDIGSES TEDQAMEDIK(Q) & $2 \mathrm{P}$ \\
\hline & 2856.1 & 2856.1 & 37 & -60 & (K)VNELSKDIGSES TEDQAMEDIKQM(E) & $2 \mathrm{P}$ \\
\hline & 3113.2 & 3113.3 & 35 & -60 & (K)EK VNELSKDIGS ES TEDQAMEDIKQM(E) & $2 \mathrm{P}$ \\
\hline & 3193.2 & 3193.3 & 35 & -60 & (K)EK VNELS KDIGSES TEDQAMEDIKQM(E) & $3 \mathrm{P}$ \\
\hline & 3699.6 & 3699.5 & 61 & -90 & (M)EAESIS S S EEIVPNS VEQKHIQKEDVPSER(Y) & $4 \mathrm{P}$ \\
\hline & 3779.6 & 3779.5 & 61 & - 90 & (M)EAES IS S S EEIVPNS VEQKHIQKEDVPSER(Y) & $5 \mathrm{P}$ \\
\hline & 3974.5 & 3974.6 & 59 & -90 & (K)QMEAESIS S S EEIVPNS VEQKHIQKEDVPSER(Y) & 4P; Oxidation (Met) \\
\hline & 4479.0 & 4479.0 & 23 & -60 & (R)FFVAPFPEVFGKEKVNELSKDIGSES TEDQAMEDIKQM(E) & $2 \mathrm{P}$ \\
\hline \multirow[t]{11}{*}{$\alpha_{\mathrm{s} 2}-\mathrm{CN}$} & 1432.6 & 1432.6 & 135 & -146 & (N)SKKTVDMESTEV(F) & $1 \mathrm{P}$ \\
\hline & 1538.6 & 1538.6 & 126 & - 137 & (R)EQLSTSEENSKK(T) & $2 \mathrm{P}$ \\
\hline & 1578.6 & 1578.6 & 123 & - 134 & (T)LNREQLSTSEEN(S) & $2 \mathrm{P}$ \\
\hline & 1694.7 & 1694.7 & 125 & -137 & (N)REQLSTSEENSKK(T) & $2 \mathrm{P}$ \\
\hline & 1793.7 & 1793.7 & 123 & -136 & (T)LNREQLSTSEENSK(K) & $2 \mathrm{P}$ \\
\hline & 1921.8 & 1921.8 & 123 & - 137 & (T)LNREQLSTSEENSKK(T) & $2 \mathrm{P}$ \\
\hline & 2715.3 & 2715.3 & 115 & - 137 & (R)NAVPITPTLNREQLSTSEENSKK(T) & $2 \mathrm{P}$ \\
\hline & 3051.3 & 3051.2 & 1 & -24 & KNTMEHVSS S EESIISQETYKQEK(N) & $3 \mathrm{P}$ \\
\hline & 3131.2 & 3131.2 & 1 & -24 & KNTMEHVS SS EESIISQETYKQEK(N) & $4 \mathrm{P}$ \\
\hline & 3786.6 & 3786.6 & 115 & -146 & (R)NAVPITPTLNREQLS TSEENSKKTVDMESTEV(F) & $3 \mathrm{P}$ \\
\hline & 4034.6 & 4034.8 & 115 & -148 & (R)NAVPITPTLNREQLS TS EENSKKTVDMESTEVFT(K) & $3 \mathrm{P}$ \\
\hline \multirow[t]{14}{*}{$\beta-\mathbf{C N}$} & 1600.7 & 1600.7 & 29 & -40 & (K)KIEKFQSEEQQQ(T) & $1 \mathrm{P}$ \\
\hline & 1785.7 & 1785.7 & 35 & -48 & (Q)SEEQQQTEDELQDK(I) & $1 \mathrm{P}$ \\
\hline & 1945.8 & 1945.8 & 29 & -43 & (K)KIEKFQSEEQQQTED(E) & $1 \mathrm{P}$ \\
\hline & 2559.2 & 2559.1 & 29 & -48 & (K)KIEKFQSEEQQQTEDELQDK(I) & $1 \mathrm{P}$ \\
\hline & 2805.2 & 2805.2 & 1 & -24 & RELEELNVPGEIVESLSS SEESIT(R) & $2 \mathrm{P}$ \\
\hline & 2885.2 & 2885.2 & 1 & -24 & RELEELNVPGEIVESLS S S EESIT(R) & 3P \\
\hline & 2906.3 & 2906.3 & 29 & -51 & (K)KIEKFQSEEQQQTEDELQDKIHP(F) & $1 \mathrm{P}$ \\
\hline & 2961.3 & 2961.3 & 1 & -25 & RELEELNVPGEIVESLSS SEESITR(I) & $2 \mathrm{P}$ \\
\hline & 2965.3 & 2965.2 & 1 & -24 & RELEELNVPGEIVES LSSS EESIT(R) & $4 \mathrm{P}$ \\
\hline & 3041.2 & 3041.3 & 1 & -25 & RELEELNVPGEIVESLS S S EESITR(I) & $3 \mathrm{P}$ \\
\hline & 3053.4 & 3053.4 & 29 & -52 & (K)KIEKFQSEEQQQTEDELQDKIHPF(A) & 1P \\
\hline & 3121.1 & 3121.3 & 1 & -25 & RELEELNVPGEIVES LS S SEESITR(I) & $4 \mathrm{P}$ \\
\hline & 3396.5 & 3396.5 & 1 & -28 & RELEELNVPGEIVESLS S SEESITRINK(K) & $3 \mathrm{P}$ \\
\hline & 3476.5 & 3476.5 & 1 & -28 & RELEELNVPGEIVES LS S S EESIT RINK(K) & $4 \mathrm{P}$ \\
\hline
\end{tabular}

* indicates a CPP containing the alternative non-allelic deletion of $\operatorname{Gln}^{78}$ [137]; Phosphoserine residues are coloured red.

Table 6. CPP identified in a commercial CPP preparation (Tatua Co-operative Dairy Company Ltd) by tandem MS sequencing.

\subsection{Examples of industrial methods for CPP preparation}

Starting from $\mathrm{CN}$, the overall preparation process gave 16\% CPP (Figure 10), less than the theoretical yield of $23 \%$ ( $Y_{\text {theor }}=22.8 \%$ ), which means approximately $20 \%$ yield on the basis of weight, a yield higher than that obtained by other researchers [138-140]. In their production 
experiments, the authors obtained a CPP preparation as high as $18.8 \%$ degree of hydrolysis $(\mathrm{DH})$.

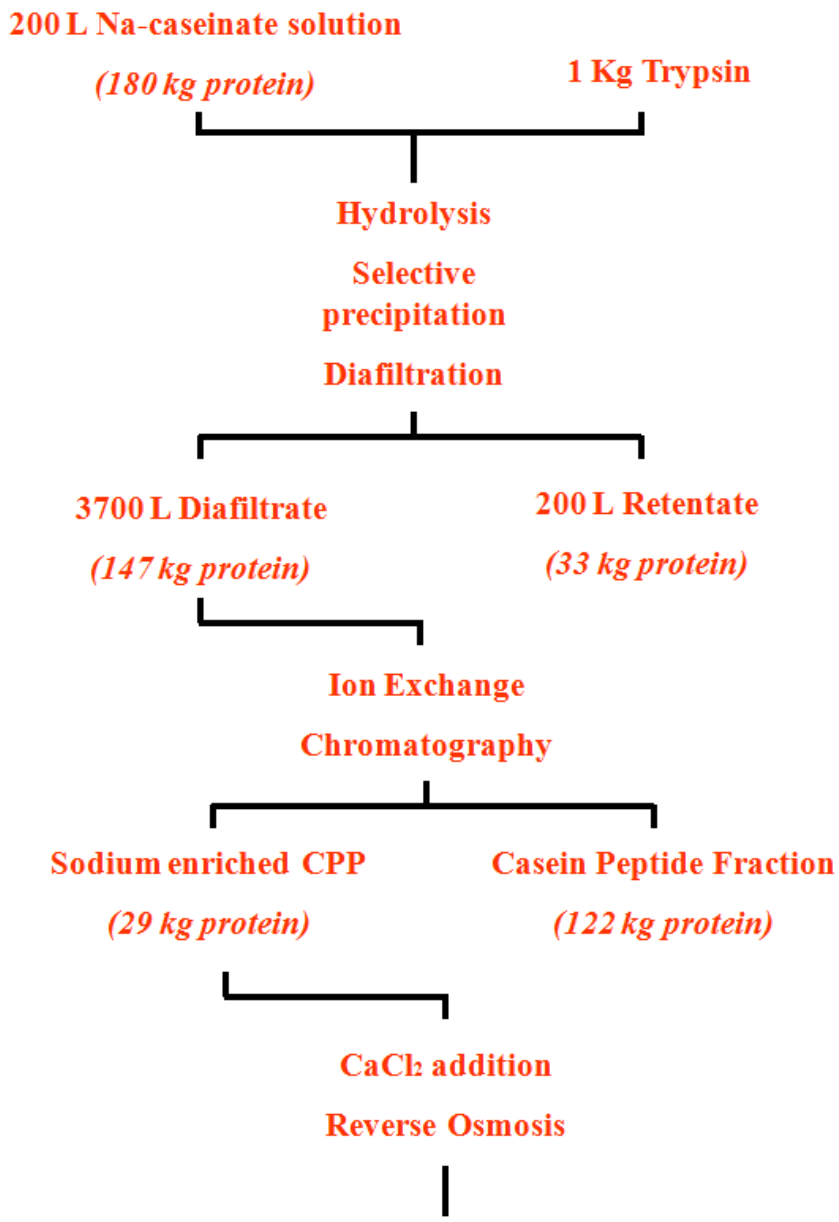

\section{Calcium enriched CPP}

(29 $\mathrm{kg}$ protein)

Figure 10. Schematic representation of the process-scale isolation of tryptic CPP from caseinate, showing the protein flow through the process (source: [141]).

The example of $2000 \mathrm{~L} \mathrm{Na}$-caseinate solution containing $180 \mathrm{~kg}$ protein and $1 \mathrm{~kg}$ trypsin yielded $29 \mathrm{~kg}$ of calcium-enriched CPP, corresponding to a yield of $16 \%(\mathrm{w} / \mathrm{w})$ [141]. A variety of raw materials such as acid casein, sodium caseinate, and calcium caseinate, as well as skimmed raw milk, milk concentrate by ultrafiltration, pasteurized and UHT milk near the limit date for consumption, may be used as the substrate for CPP production. The 
optimal parameters for the hydrolysis with trypsin were $37^{\circ} \mathrm{C}$ and $\mathrm{pH}$ between 7.5 and 8.5. The casein hydrolysate solution was roughly fractioned by ultrafiltration with appropriate membranes to obtain soluble CPP both in the "permeate" and "retentate". Lower-molecular peptides/phosphopeptides occurred in the "permeate" and larger in the "retentate". The diafiltrate containing the tryptic casein digest was loaded on the ion exchange resin, and the non-CPP flowed through and were recovered for further use, e.g., as substrate for bacterial culture. Bound CPP, free of non-CPP, are eluted using sodium hydroxide, e.g., $0.2 \mathrm{M}$, and conductivity and absorbance monitored at $280 \mathrm{~nm}$. The eluate containing CPP is collected and then concentrated, typically by reverse osmosis. Peptides were pasteurized $\left(85^{\circ} \mathrm{C}, 15 \mathrm{~s}\right)$ and spray dried, yielding sodium enriched $\mathrm{CPP}(\mathrm{Na}-\mathrm{CPP})$. In other cases, to obtain calciumenriched $\mathrm{CPP}$, the concentrate is added with $\mathrm{CaCl}_{2}$ in excess, diafiltered, and then CPP solution concentrated by reverse osmosis until the filtrate conductivity was negligible (less than $\left.3 \mathrm{mS} \mathrm{cm}^{-1}\right)$. The concentrate is spray dried, and the product is labeled as calciumenriched CPP (Ca-CPP).

\subsection{Traditional and new processes for the use of CPP in alimentary products}

$\mathrm{A} \mathrm{Ca}^{2+} /$ ethanol selective precipitation procedure was used to produce a CPP and non-CPP concurrently from an alcalase digest of whole casein in which the traditional and new processes for CPP production were reported [142]. CN is trypsinized, and the $\mathrm{pH}$ of the solution is adjusted to 4.6 to separate the non-peptide material. The $\mathrm{CPP}-\mathrm{Ca}^{2+}$ aggregation was induced by ethanol addition in the supernatant and recovered as precipitate for freeze drying. In the novel process, the step of non-peptide material removal was omitted, and non-CPP (CNPP) was recovered as supernatant for use in alimentary products. For casein, the use of alcalase, a cheap enzyme suitable for industrial application, for hydrolysis was suggested [142]. The CN hydrolysates were separated into the two types of peptides using combined treatment with $\mathrm{CaCl}_{2}$ and ethanol. CPP and non-CPP comprised components with molecular weight lower than $2509 \mathrm{Da}$ and $2254 \mathrm{Da}$, respectively, as determined using size exclusion HPLC. A DH of $20 \%$ for the CN hydrolysate was achieved. At the end, the recovery of CPP reached $24 \%$. The phosphorus component of CPP was 3.08\%, and nitrogen recovery was approximately $76 \%$ [142]. CPP generally had an improved solubility and transparency even under acid conditions and could be used as ingredient for beverages such as sport drinks, soft drinks, health drinks, fermented products, vitamin concentrates, fruit or fruit fractions.

\subsection{Patented methods for CPP production as ingredients for alimentary products}

A method for the preparation of selected anticariogenic CPP comprised the steps of complete digestion of $\mathrm{CN}$ as soluble monovalent cation salt with a proteolytic enzyme: the addition of a mineral acid to the solution to adjust the $\mathrm{pH}$ to approximately 4.7 ; the removal of any produced precipitate; the addition of $\mathrm{CaCl}_{2}$ to a concentration of approximately $1.0 \%$ $(\mathrm{w} / \mathrm{v})$ to cause the aggregation of CPP; the separation of the aggregated CPP from the solution through a filter with a molecular weight exclusion limit within the range 10000 to 
20000 while passing the bulk of the remaining CPP in solution; the diafiltration of the separated CPP with water through a filter; the concentration of the solution; and the drying the retentate [143]. Peptides not included in the aggregation were removed by ultrafiltration/diafiltration. By this means, anticariogenic CPP at purity greater than $90 \%$ were obtained [143]. CPP including calcium, magnesium or both salts (or zinc, ferric or other salts) are produced by submitting $\mathrm{CN}$ to proteolytic enzyme hydrolysis, ultrafiltering the resulting hydrolyzate to produce a permeate containing $\mathrm{CPP}$, adding a bivalent cation salt to the peptides to form CPP aggregates, and separating by ultrafiltration the CPP aggregates and non-CPP [144]. When CPP salts need to be converted to free phosphopeptides, they can be restored by acidification with $\mathrm{HCl}$; the solution is then diafiltered extensively through a 1000 molecular weight cut-off membrane to remove excess calcium chloride.

\subsection{Example of CPP applications as nutraceuticals in functional foods}

The CPP-salts complex can be added to different foods. A stable acidic beverage or other alimentary products can be obtained by digesting casein with trypsin, precipitating the insoluble components at acid $\mathrm{pH}$, adjusting the $\mathrm{pH}$ of the obtained supernatant to approximately 6.0, then adding calcium chloride and ethanol to recover an acid-soluble calcium complex of CPP and the reaction product and adding them to a soft drink [145]. The acid-soluble calcium complex of CPP enhances calcium absorption from food because calcium may be absorbed by the body in the form of soluble calcium. Acid-soluble CPP is a mixture of $\alpha_{\mathrm{s} 1}-, \alpha_{\mathrm{s} 2}-$ and $\beta$-CPP, forming essentially no turbidity in solution at $\mathrm{pH}$ of 3.0 or less, and having purity greater than $90 \%$, molecular weights between approximately 2500 and $4600 \mathrm{Da}$, and the ability to solubilize at least $100 \mathrm{ppm}$ calcium at a concentration of 0.5 $\mathrm{mg} / \mathrm{ml} \mathrm{CPP}$. The acid-soluble CPP produced in vitro also have a solubilizing capability on iron. It is widely believed that iron must be solubilized for absorption through the small intestine. Accordingly, health may also be enhanced by the absorption of the soluble iron in the drink by the human body. Similarly, magnesium may be solubilized in a drink or edible product of this type [145]. Therefore, in addition to drinks, preparation of CPP with high negative charge could be used as additive for healthy foods or for dietetic or pharmaceutical compositions, as they are capable of increasing the in vivo absorption of calcium or other ions [146]. Another interesting invention relates to processes and the compositions that are useful to remineralize the teeth of mammals, particularly humans, and impart acid resistance thereto. These compositions included a gum base or carrier, sweetening agents, CPP-ACP preparation and food-grade acids [147]. Because many chewing gum and confectionery products usually contain acids, many consumers enjoying chewing gum and confectionery products ingest acids causing demineralization of the tooth surface. CPPcalcium phosphate complexes are known to have anticariogenic teeth strengthening effects that could be used address the problem of dissolution or demineralization of tooth enamel and the resultant formation of dental caries. Exogenous CPP-ACP preparations have also been added to milk in 2.0-5.0 gL amounts to remineralize enamel subsurface lesions, which actually increased with respect to the control [148]. 
These inventions create functional foods with undoubted beneficial effects on human health, possibly promoting recalcification of bones, protecting the tooth enamel from decay and other possible health benefits.

\section{Conclusion}

Proteins are no longer considered merely nutritional components because they possess encrypted peptides with possible biological properties [149-153]. The cited literature has highlighted that bioactive peptides may be released in vitro or in vivo by digestive and bacterial enzymes starting from casein or generally inactive precursors [151,154-155]. We have examined the case of casein-derived phosphopeptides that can be applied as dietary supplements in "functional foods" and produced on an industrial scale. With this, it has been demonstrated that, each time a health-enhancing nutraceutical is required for a functional food, an appropriate enzymatic hydrolysis of casein needs to be designed [156-157]. In addition to the anticariogenic activity, the most important function displayed by CPP is that soluble and encrypted casein phosphopeptides can arrive without modification of the phosphorylated sequence to the brush border membrane. It is postulated that short-sequence peptides reach their putative receptors in many tissues without modification. Whether they enter blood circulation or whether their action is restricted to a peripheral circle are current questions that await response. In conclusion, this review has considered milk and cheese CPP for specific food ingredients. The contribution of in vitro casein digests by gastric proteases to potential biologically active substances in the intestine must be simultaneously considered. Scientists are currently involved in investigations to define the in vivo fate of all of the bioactive peptides. The in vitro studies have allowed the scientists to compare the predicted and the experimental sequence of CPP. This step is preliminary to the clinical investigations designed to determine the bioactivity of the milk hydrolysates. These findings open an industrial perspective that will permit the unrestricted use of CPP in healthy promoting food application.

\section{Author details}

Gabriella Pinto, Marina Cuollo, Sergio Lilla, Lina Chianese and Francesco Addeo Department of Food Science, University of Naples "Federico II", Parco Gussone, Portici (Naples), Italy

Simonetta Caira

Food Science Institute of the National Research Council (C.N.R.), Via Roma, Avellino, Italy

\section{Acknowledgments}

Publication in partial fulfilment of the requirements for $\mathrm{PhD}$ in Sciences and Technologies of Food Productions - XXV Cycle, University of Naples 'Federico II'. The Authors gratefully 
acknowledge the American Journal Experts Association for the text revision (http://www.journalexperts.com/). This work was partly supported by the financial aid to C.L. from MIUR, Program PRIN-2008 HNHAT7-004.

\section{References}

[1] Lambert JD, Hong J, Yang GY, Liao J, Yang CS. Inhibition of Carcinogenesis by Polyphenols: Evidence from Laboratory Investigations. American Society for Clinical Nutrition 2005;81(1) 284S-291S.

[2] Aggarwal BA, Shishodia S. Molecular Targets of Dietary Agents for Prevention and Therapy of Cancer. Biochemical Pharmacology 2006;71(10) 1397-1421.

[3] Chang DS. Preparations for Sustained Release of Nutraceuticals and Methods of Controllably Releasing Nutraceuticals. US Patent 07115283.

[4] Cartwright R, Hendricks LE. Nutraceutical Composition. US Patent 20030091552.

[5] Torres-Giner S, Martinez-Abad A, Ocio MJ, Lagaron JM. Stabilization of a Nutraceutical Omega-3 Fatty Acid by Encapsulation in Ultrathin Electrosprayed Zein Prolamine. Journal of Food Science 2010;75(6) N69-79.

[6] Mora-Gutierrez A, Gurin MH. Bioactive Complexes Compositions and Methods of Use Thereof. US Patent 7780873.

[7] Policker Y. Nutraceutical Sweetener Composition. US Patent 2010/0068347.

[8] Schanbacher FL, Talhouk RS, Murray FA, Gherman LI, Willett LB. Milk-Borne Bioactive Peptides. International Dairy Journal 1998;8(5) 393-403.

[9] Husson SJ, Landuyt B, Nys T, Baggerman G, Boonen K, Clynen E, Lindemans M, Janssen T, Schoofs L. Comparative Peptidomics of Caenorhabditis Elegans versus C. Briggsae by LC-MALDI-TOF MS. Peptides 2009;30(3) 449-457.

[10] Fosset S, Tomé D. Nutraceuticals from Milk. In: Roginski H, Fuquay JW, Fox PF. (ed.) Enciclopedia Dairy Science. London: Accasemy Press; 2003. p2108-2112.

[11] Silva SV, Malcata FX. Caseins as Source of Bioactive Peptides. International Dairy Journal 2005;15(1) 1-15.

[12] Recio Sanchez I. Bioactive Peptides Identified in Enzymatic Hydrolyzates of Milk Caseins and Method of Obtaining Same. US 2010/0048464.

[13] FitzGerald RJ. Potential Uses of Caseinophosphoeptides. International Dairy Journal 1998;8(5-6) 451-457.

[14] Luo SJ, Wong LL. Oral Care Confections and Method of Using. US Patent 6733818.

[15] Reynolds EC, Cai F, Shen P, Walker GD. Retention in Plaque and Remineralization of Enamel Lesions by Various Forms of Calcium in a Mouthrinse or Sugar-free Chewing Gum. Journal of Dental Research 2003;82(3) 206-211.

[16] Korhonen H, Pihlanto A. Bioactive Peptides: Production and Functionality. International Dairy Journal 2006;16(9) 945-960.

[17] Law J, Haandrikman A. Proteolytic Enzymes of Lactic Acid Bacteria. International Dairy Journal 1997;7(1) 1-11. 
[18] Gatti M, Fornasari ME, Mucchetti G, Addeo F, Neviani E. Presence of Peptidase Activities in Different Varieties of Cheese. Letters in Applied Microbiology 1999;28(5) 368-372.

[19] Léonila J, Gagnaire V, Mollé D, Pezennec S, Bouhallab S. Application of Chromatography and Mass Spectrometry to the Characterization of Food Proteins and Derived Peptides. Journal of Chromatography A 2000;881(1-2) 1-21.

[20] Christensen JE, Dudley EG, Pederson JA, Steele JL. Peptidases and Amino Acid Catabolism in Lactic Acid Bacteria. Antonie Van Leeuwenhoek 1999;76(1-4) 217246.

[21] Kunji ERS, Mierau I, Hagting A, Poolman B, Konings WN. The Proteolytic Systems of Lactic Acid Bacteria. Antonie Van Leeuwenhoek 1996;70(2-4) 187-221.

[22] Doeven MK, Kok J, Poolman B. Specificity and Selectivity Determinants of Peptide Transport in Lactococcus Lactis and Other Microorganisms. Molecular Microbiology 2005;57(3) 640-649.

[23] Fernandez-Espla MD, Rul F. PepS from Streptococcus thermophilus. A New Member of the Aminopeptidase $\mathrm{T}$ Family of Thermophilic Bacteria. European Journal of Biochemistry 1999;263(2) 502-510.

[24] Gagnaire V, Piot M, Camier B, Vissers JP, Jan G, Léonil J. Survey of Bacterial Proteins Released in Cheese: a Proteomic Approach. International Journal of Food Microbiology 2004;94(2) 185-201.

[25] Saz JM, Marina ML. Application of Micro- and Nano-HPLC to the Determination and Characterization of Bioactive and Biomarker Peptides. Journal of Separation Science 2008;31(3) 446-458.

[26] Miclo L, Roux É, Genay M, Brusseaux É, Poirson C, Jameh N, Perrin C, Dary A. Variability of Hydrolysis of $\beta-, \alpha_{\mathrm{s}^{-}-}$, and $\alpha_{\mathrm{s} 2}$-Caseins by 10 Strains of Streptococcus thermophilus and Resulting Bioactive Peptides. Journal of Agricultural and Food Chemistry 2012;60(2) 554-565.

[27] Pihlanto-Leppälä A, Rokka T, Korhonen H. Angiotensin I Converting Enzyme Inhibitory Peptides Derived from Bovine Milk Proteins. International Dairy Journal 1998;8(4) 325-331.

[28] Pélissier JP. Protéolyse des Caséines. Sciences des Aliments 1984;4(1) 1-35.

[29] Teschemacher H, Koch G, Brantl V. Milk Protein-Derived Opioid Receptor Ligands. Biopolymers 1997;43(2) 99-117.

[30] Meisel H. Chemical Characterization and Opioid Activity of an Exorphin Isolated from in Vivo Digests of Casein. FEBS Letters 1986;196(2) 223-227.

[31] Ondetti MA, Cushman DW. Enzymes of the Renin-Angiotensin System and their Inhibitors. Annual Review of Biochemistry 1982;51 283-308

[32] Bruneval P, Hinglais N, Alhenc-Gelas F. Angiotensin I Converting Enzyme in Human Intestine and Kidney. Ultrastructural Immunohistochemical Localization. Histochemistry 1986;85(1) 73-80.

[33] Meisel H. Casokinins as Bioactive Peptides in the Primary Structure of Casein. In Schwenke KD, Mothes R. (ed.) Food Proteins: Functionality. New York: VCHWeinheim; 1993. p67-75. 
[34] Sato R, Noguchi T, Naito H. Casein phosphopeptide (CPP) Enhances Calcium Absorption from the Ligated Segment of Rat Small Intestine. Journal of Nutritional Science and Vitaminology 1986;32(1) 67-76.

[35] Reynolds EC. Remineralization of Enamel Subsurface Lesions by Casein Phosphopeptide-Stabilized Calcium Phosphate Solutions. Journal of Dental Research 1997;76(9) 1587-1595.

[36] Meisel H, Olieman C. Estimation of Calcium binding Constants of Casein Phosphopeptides by Capillary Zone Electrophoresis. Analytica Chimica Acta 1998;372(1-2) 291-297.

[37] Hala I, Higashiyama S, Otani H. Identification of a Phosphopeptide in Bovine $\alpha_{\mathrm{s} 1-}$ Casein Digest as a Factor Influencing Proliferation and Immunogloblin Production in Lymphocyte Cultures. Journal of Dairy Research 1998;65(4) 569-578.

[38] Hala I, Ueda J, Otani H. Immunostimulatory Action of a Commercially Available Casein Phosphopeptide Preparation, CPP-III. in Cell Cultures. Milchwissenschaft 1999; 54(1) 3-7.

[39] Loukas S, Varoucha D, Zioudrou C, Streaty R, Klee WA. Opioid Activities and Structures of alpha-Casein-Derived Exorphins. Biochemistry 1983;22(19) 45674573.

[40] Loukas S, Panetsos F, Donga E, Zioudrou C. Selective $\delta$-Antagonist Peptides, Analogs of $\alpha$-Casein Exorphin, as Probes for the Opioid Receptor In: Nyberg F. Brantl V. (ed.) $\beta$ Casomorphins and Related Peptides. Uppsala: Fyris-Tryck AB; 1990. p143149.

[41] Pihlanto-Leppälä A, Antila P, Mäntsälä P, Hellman J. Opioid Peptides Produced by in Vitro Proteolysis of Bovine Caseins. International Dairy Journal 1994;4(4) 291301.

[42] Miquel E, Gómez JÁ, Alegría A, Barberá R, Farré R Recio I. Identification of Casein Phosphopeptides after Simulated Gastrointestinal Digestion by Tandem Mass Spectrometry. European Food Research and Technology 2006;222(1-2) 48-53.

[43] Picariello G, Ferranti P, Fierro O, Mamone G, Caira S, Di Luccia A, Monica S, Addeo F. Peptides Surviving the Simulated Gastrointestinal Digestion of Milk Proteins: Biological and Toxicological Implications. Journal of Chromatography B. Analytical Technologies in the Biomedical and Life Sciences 2010;878(3-4) 295-308.

[44] Farrell HM Jr, Jimenez-Flores R, Bleck GT, Brown EM, Butler JE, Creamer LK, Hicks CL, Hollar CM, Ng-Kwai-Hang KF, Swaisgood HE. Nomenclature of the Proteins of Cows' Milk-Sixth Revision. Journal of Dairy Science 2004;87(6) 1641-1674.

[45] Kenny AJ, Maroux S. Topology of Microvillar Membrance Hydrolases of Kidney and Intestine. Physiological Reviews 1982;62(1) 91-128.

[46] Yoshioka M, Erickson RH, Woodley JF, Gulli R, Guan D, Kim YS. Role of Rat Intestinal Brush-Border Membrane Angiotensin-Converting Enzyme in Dietary Protein Digestion. American Journal of Physiology-Gastrointestinal and Liver Physiology 1987;253(6 Pt 1) G781-G786. 
[47] Erickson RH, Song IS, Yoshioka M, Gulli R, Miura S, Kim YS. Identification of ProlineSpecific Carboxypeptidase Localized to Brush Border Membrane of Rat Small Intestine and its Possible Role in Protein Digestion. Digestive Diseases and Sciences 1989;34(3) 400-406.

[48] Mellander O, Folsch G. Enzyme Resistance and Metal Binding of Phosphorylated Peptides. In: Bigwood EJ. (ed.) Protein and Amino Acid Function. New York: Pergamoon Press Inc; 1972. p569-79.

[49] Boutrou, R, Coirre E, Jardin J, Léonil J. Phosphorylation and Coordination Bond of Mineral Inhibit the Hydrolysis of the $\beta$-Casein (1-25) Peptide by Intestinal Brush-Border Membrane Enzymes. Journal of Agricultural and Food Chemistry 2010;58(13) 79557961.

[50] Kibangou IB, Bouhallab S, Henry G, Bureau F, Allouche S, Blais A, Guérin P, Arhan P, Bouglé DL. Milk Proteins and Iron Absorption: Contrasting Effects of Different Caseinophosphopeptides. Pediatric Research 2005;58(4) 731-734.

[51] Pérès JM, Bouhallab S, Petit C, Bureau F, Maubois JL, Arhan P, Bougle D. Improvement of Zinc Intestinal Absorption and Reduction of Zinc/Iron Interaction Using Metal Bound to the Caseinophosphopeptide 1-25 of $\beta$-casein. Reproduction, Nutrition \& Development 1998;38(4) 465-472.

[52] Kasai T, Iwasaki R, Tanaka M, Kiriyama S. Caseinphosphopeptides (CPP) in Feces and Contents in Digestive Tract of Rats Fed Casein and CPP Preparations. Bioscience, Biotechnology and Biochemistry 1995;59(1) 26-30.

[53] Ferraretto A, Signorile A, Gravaghi C, Fiorilli A, Tettamanti G. Casein Phosphopeptides Influence Calcium Uptake by Cultured Human Intestinal HT-29 Tumor Cells. Journal of Nutrition 2001;131(6) 1655-1661.

[54] Richter S, Bergmann R, Pietzsch J, Ramenda T, Steinbach J, Wuest F. Fluorine-18 Labeling of Phosphopeptides: A Potential Approach for the Evaluation of Phosphopeptide Metabolism In Vivo. Biopolymers 2009;92(6) 479-488.

[55] Erba D, Ciappellano S, Testolin G. Effect of Caseinphosphopeptides on Inhibition of Calcium Intestinal Absorption due to Phosphate. Nutrition Research 2001;21(4) 649656.

[56] Marcus CS, Lengemann FW. Absorption of $\mathrm{Ca}^{45}$ and $\mathrm{Sr}^{85}$ from Solid and Liquid Food at Various Levels of the Alimentary Tract of the Rat. Journal of Nutrition 1962;77(2) 155160.

[57] Marcus CS, Lengemann FW. Use of Radioyttrium to Study Food Movement in the Small Intestine of the Rat. Journal of Nutrition 1962;76(2) 179-182.

[58] Meisel H, Bernard H, Fairweather-Tait S, FitzGerald RJ, Hartmann R, Lane CN, McDonagh D, Teucher B, Wal JM. Detection of Caseinophosphopeptides in the Distal Ileostomy Fluid of Human Subjects. British Journal of Nutrition 2003;89(3) 351359. 
[59] Meisel H, Frister H. Chemical Characterization of a Caseinophosphopeptide Isolated from in Vivo Digests of a Casein Diet. Biological Chemistry Hoppe-Seyler 1988;369(12) 1275-1279.

[60] Chabance B, Marteau P, Rambaud JC, Migliore-Samour D, Boynard M, Perrotin P, Guillet R, Jollès P, Fiat AM. Casein Peptide Release and Passage to the Blood in Humans during Digestion of Milk or Yogurt. Biochimie 1998;80(2) 155-165.

[61] Meisel H. Biochemical Properties of Regulatory Peptides Derived from Milk Proteins. Biopolymers 1997;43(2) 119-128.

[62] Sato R, Noguchi T, Naito H. Casein phosphopeptide (CPP) Enhances Calcium Absorption from the Ligated Segment of Rat Small Intestine. Journal of Nutritional Science and Vitaminology 1986;32(1) 67-76.

[63] Ferraretto A, Gravaghi C, Fiorilli A, Tettamanti G. Casein-Derived Bioactive Phosphopeptides: Role of Phosphorylation and Primary Structure in Promoting Calcium Uptake by HT-29 Tumor Cells. FEBS Letters 2003;551(1-3) 92-98.

[64] Cosentino S, Gravaghi C, Donetti E, Donida BM, Lombardi G, Bedoni M, Fiorilli A, Tettamanti G, Ferraretto A. Caseinphosphopeptide-Induced Calcium Uptake in Human Intestinal Cell Lines HT-29 and Caco2 is Correlated to Cellular Differentiation. Journal of Nutritional Biochemistry 2010;21(3) 247-254.

[65] Donida BM, Mrak E, Gravaghi C, Villa I, Cosentino S, Zacchi E, Perego S, Rubinacci A, Fiorilli A, Tettamanti G, Ferraretto A. Casein Phosphopeptides Promote Calcium Uptake and Modulate the Differentiation Pathway in Human Primary Osteoblast-like Cells. Peptides 2009;30(12) 2233-2241.

[66] Reynolds EC. Casein Phosphopeptide-Amorphous Calcium Phosphate: The Scientific Evidence. Advances in Dental Research 2009;21(1) 25-29.

[67] Rose RK. Binding Characteristics of Streptococcus mutans for Calcium and Casein Phosphopeptide. Caries Res 2000;34(5) 427-431.

[68] McCormack AL, Schieltz DM, Goode B, Yang S, Barnes G, Drubin D, Yates JR III. Direct Analysis and Identification of Proteins in Mixtures by LC/MS/MS and Database Searching at the Low-femtomole Level Analytical Chemistry 1997;69(4):767776.

[69] Eng JK, McCormack AL, Yates JR III. An Approach to Correlate Tandem Mass Spectral Data of Peptides with Amino Acid Sequences in a Protein Database. Journal of The American Society for Mass Spectrometry 1994;5(11) 976-989.

[70] Stensballe A, Andersen S, Jensen ON. Characterization of Phosphoproteins from Electrophoretic Gels by Nanoscale Fe(III) Affinity Chromatography with Off-line Mass Spectrometry Analysis. Proteomics 2001;1(2) 207-222.

[71] Craig AG, Hoeger CA, Miller CL, Goedken T, Rivier JE, Fischer WH. Monitoring Protein Kinase and Phosphatase Reactions with Matrix-Assisted Laser Desorption/Ionization Mass Spectrometry and Capillary Zone Electrophoresis: Comparison of the Detection Efficiency of Peptide-Phosphopeptide Mixtures. Biological Mass Spectrometry 1994;23(8) 519-528. 
[72] Annan RS, Huddleston MJ, Verma R, Deshaies RJ, Carr SA. A Multidimensional Electrospray MS-Based Approach to Phosphopeptide Mapping. Analytical Chemistry 2001;73(3) 393-404.

[73] Manson W, Annan WD. The Structure of a Phosphopeptide Derived from $\beta$-casein. Archives of Biochemistry and Biophysics 1971;145(1) 16-26.

[74] Gygi SP, Corthals GL, Zhang Y, Rochon Y, Aebersold R. Evaluation of two-Dimensional Gel Electrophoresis-Based Proteome Analysis Technology. PNAS 2000;97(17) 93909395.

[75] Oda Y, Nagasu T, Chait, BT. Enrichment Analysis of Phosphorylated Proteins as a Tool for Probing the Phosphoproteome. Nature Biotechnology 2001;19(4) 379-382.

[76] Zhou H, Watts, JD, Aebersold R. A Systematic Approach to the Analysis of Protein Phosphorylation. Nature Biotechnology 2001;19(4) 375-378.

[77] Posewitz MC, Tempst P. Immobilized Gallium(III) Affinity Chromatography of Phosphopeptides. Analytical Chemistry 1999;71(14) 2883-2892.

[78] Kokubu M, Ishihama Y, Sato T, Nagasu T, Oda Y. Specificity of Immobilized Metal Affinity-Based IMAC/C18 Tip Enrichment of Phosphopeptides for Protein Phosphorylation Analysis. Analytical Chemistry 2005;77(16) 5144-5154.

[79] Machida M, Kosako H, Shirakabe K, Kobayashi M, Ushiyama M, Inagawa J, Hiran J, Nakano T, Bando Y, Nishida E, Hattori S. Purification of Phosphoproteins by Immobilized Metal Affinity Chromatography and its Application to Phosphoproteome Analysis. FEBS Journal 2007;274(6) 1576-1587.

[80] Thingholm TE, Jensen ON. Enrichment and Characterization of Phosphopeptides by Immobilized Metal Affinity Chromatography (IMAC) and Mass Spectrometry. Methods in Molecular Biology 2009;527 47-56.

[81] Pinkse MWH, Uitto PM, Hilhorst MJ, Ooms B, Heck AJ Selective Isolation at the Femtomole Level of Phosphopeptides from Proteolytic Digests Using 2D-NanoLC-ESIMS/MS and Titanium Oxide Precolumns. Analytical Chemistry 2004;76(14) 39353943.

[82] Rinalducci S, Larsen MR, Mohammed S, Zolla L. Novel Protein Phosphorylation Site Identification in Spinach Stroma Membranes by Titanium Dioxide Microcolumns and Tandem Mass Spectrometry. Journal of Proteome Research 2006;5(4) 973-982.

[83] Thingholm TE, Jørgensen TJ, Jensen ON, Larsen MR. Highly Selective Enrichment of Phosphorylated Peptides using Titanium Dioxide. Nature Protocols 2006;1(4) 19291935.

[84] Dunn JD, Reid GE, Bruening ML. Techniques for Phosphopeptide Enrichment prior to Analysis by Mass Spectrometry. Mass Spectrometry Reviews 2010;29(1) 29-54.

[85] Moser K, White FM. Phosphoproteomic Analysis of Rat Liver by High Capacity IMAC and LC-MS/MS. Journal of Proteome Research 2006;5(1) 98-104.

[86] Larsen MR, Thingholm TE, Jensen ON, Roepstorff P, Jorgensen TJD. Highly Selective Enrichment of Phosphorylated Peptides from Peptide Mixtures Using Titanium Dioxide Microcolumns. Molecular \& Cellular Proteomics 2005;4(7) 873-886. 
[87] Bodenmiller B, Mueller LN, Mueller M, Domon B, Aebersold R. Reproducible Isolation of Distinct, Overlapping Segments of the Phosphoproteome. Nature Methods 2007;4(3) 231-237.

[88] Sugiyama N, Masuda T, Shinoda K, Nakamura A, Tomita M, Ishihama Y. Phosphopeptide Enrichment by Aliphatic Hydroxyl Acid-Modified Metal Oxide Chromatography for Nano-LC-MS/MS in Proteomics Applications. Molecular \& Cellular Proteomics 2007;6(6) 1103-1109.

[89] McLachlin DT, Chait BT. Analysis of Phosphorylated Proteins and Peptides by Mass Spectrometry. Current Opinion in Chemical Biology 2001;5(5) 591-602.

[90] Pinto G, Caira S, Cuollo M, Lilla S, Fierro O, Addeo F. Hydroxyapatite as a Concentrating Probe for Phosphoproteomic Analyses. Journal of Chromatography B 2010;878(28) 2669-2678.

[91] Zhou HY, Salih E, Glimcher MJ. Isolation of a Novel Bone Glycosylated Phosphoprotein with Disulphide Cross-Links to Osteonectin. Biochemical Journal 1998;330(3) 14231431.

[92] Schmidt SR, Schweikart F, Andersson ME. Current Methods for Phosphoprotein Isolation and Enrichment. Journal of Chromatography B 2007;849(1-2) 154-162.

[93] Kawasaki T. Hydroxyapatite as a Liquid Chromatographic Packing. Journal of Chromatography A 544(17) 147-184.

[94] Mamone G, Picariello G, Ferranti P, Addeo F. Hydroxyapatite Affinity Chromatography for the Highly Selective Enrichment of Mono- and MultiPhosphorylated Peptides in Phosphoproteome Analysis. Proteomics 2010;10(3) 380393.

[95] Cirulli C, Chiappetta G, Marino G, Mauri P, Amoresano A. Identification of Free Phosphopeptides in Different Biological Fluids by a Mass Spectrometry Approach. Analytical and Bioanalytical Chemistry 2008;392(1-2) 147-159.

[96] Hu L, Zhou H, Li Y, Sun S, Guo L, Ye M, Tian X, Gu J, Yang S, Zou H. Profiling of Endogenous Serum Phosphorylated Peptides by Titanium (IV) Immobilized Mesoporous Silica Particles Enrichment and MALDI-TOFMS Detection. Analytical Chemistry 2009;81(1) 94-104.

[97] Li Y, Qi D, Deng C, Yang P, Zhang X. Cerium Ion-Chelated Magnetic Silica Microspheres for Enrichment and Direct Determination of Phosphopeptides by MatrixAssisted Laser Desorption Ionization Mass Spectrometry. Journal of Proteome Research 2008;7(4) 1767-1777.

[98] Maurer MC, Peng JL, An SS, Trosset JY, Henschen-Edman A, Scheraga, HA. Structural Examination of the Influence of Phosphorylation on the Binding of Fibrinopeptide A to Bovine Thrombin. Biochemistry 1998, 37(17) 5888-5902.

[99] Matrisian LM, Sledge GW Jr, Mohla S. Extracellular Proteolysis and Cancer: Meeting Summary and Future Directions Cancer Research 2003;63(19) 6105-6109.

[100] Resmini P, Pellegrino L, Battelli G. Accurate Quantification of Furosine in Milk and Dairy Products by a Direct HPLC Method. Italian Journal of Food Science 1990;2(3) 173183. 
[101] Corzo N, López-Fandiño R, Delgado T, Ramos M, Olano A. Changes in Furosine and Proteins of UHT-Treated Milks Stored at High Ambient Temperatures. Zeitschrift fur Lebensmittel-Untersuchung und-Forschung 1994;198(4) 302-306.

[102] Pinto G, Caira S, Cuollo M, Fierro O, Nicolai MA, Chianese L, Addeo F. Lactosylated Casein Phosphopeptides as Specific Indicators of Heated Milks. Analytical and Bioanalytical Chemistry 2012 2012;402(5) 1961-1972.

[103] Mendoza MR, Olano A, Villamiel M. Chemical Indicators of Heat Treatment in Fortified and Special Milks. Journal of Agriculture and Food Chemistry 2005;53(8) 29952999.

[104] Mottar J, Bassier A, Joniau M, Baert J. Effect of Heat-Induced Association of Whey Proteins and Casein Micelles on Yogurt Texture. Journal of Dairy Science 1989;72(9) 2247-2256.

[105] Tokusoglu Ö, Akalin AS, Unal K. Rapid High Performance Liquid Chromatographic Detection of Furosine (epsilon- N-2-furoylmethyl-L-lysine) in Yogurt and Cheese Marketed in Turkey. Journal of Food Quality 2006;29(1) 38-46.

[106] Bouhallab S, Oukhatar NA, Molle D, Henry G, Maubois JL, Arhan P, Bougle D. Sensitivity of Beta-Casein Phosphopeptide-Iron Complex to Digestive Enzymes in Ligated Segment of Rat Duodenum. The Journal of Nutritional Biochemistry 1999;10(12) 723-727.

[107] Pérès JM, Bouhallab S, Bureau P, Neuville D, Maubois JL, Devroede G, Arhan P, Bouglé D. Mechanisms of Absorption of Caseinophosphopeptide Bound Iron. The Journal of Nutritional Biochemistry 1999;10(4) 215-222.

[108] Adamson NJ, Reynolds EC. Characterization of Multiply Phosphorylated Peptides Selectively Precipitated from a Pancreatic Casein Digest. Journal of Dairy Science 1995;78(12) 2653-2659.

[109] Klaver FAM, Kingma F, Weerkamp AH. Growth and Survival of Bifidobacteria in Milk. Netherlands Milk Dairy Journal 1993;47(3-4) 151-164.

[110] Roudot-Algaron F, Le Bars D, Kerhoas L, Einhorn J, Gripon JC. Phosphopeptides from Comté Cheese. Nature and Origin. Journal of Food Science 1994; 59(3) 544547.

[111] Ferranti P, Barone F, Chianese L, Addeo F, Scaloni A, Pellegrino L, Resmini P. Phosphopeptides from Grana Padano: Nature, Origin and Changes during Ripening. Journal of Dairy Research 1997;64(4) 601-615.

[112] Lund M, Ardö Y. Purification and Identification of Water Soluble Phosphopeptides from Cheese using Fe(III) Affinity Chromatography and Mass Spectrometry. Journal of Agricultural and Food Chemistry 2004;52(21) 6616-6622.

[113] Pellegrino L, Battelli G, Resmini P, Ferranti P, Barane F, Addeo F. Effects of Heat Load Gradient Occurring in Moulding on Characterization and Ripening of Grana Padano. Lait 1997;77(2) 217-228.

[114] Walstra P, Jenness R. Dairy Chemistry and Physics. New York: John Wiley and Sons; 1984. 
[115] Pirisi A, Pinna G, Addis M, Piredda G, Mauriello R, De Pascale S, Addeo F, Chianese L. Relationship Between the Enzymatic Composition of Lamb Paste Rennet and Proteolytic and Lypolitic Pattern and Texture of PDO Fiore Sardo Cheese. International Dairy Journal 2007;17(2) 143-156.

[116] Battistotti B, Corradini C. Italian Cheese. In: Fox PF. (ed.) Cheese: Chemistry, Physics and Microbiology. Volume II. Major Cheese Groups. London: Elsevier Applied Science; 1993. p221-243.

[117] Voigt DD, Chevalier F, Qian MC, Kelly AL. Effect of High-Pressure Treatment on Microbiology, Proteolysis, Lipolysis and Levels of Flavour Compounds in Mature BlueVeined Cheese. Innovative Food Science \& Emerging Technologies 2010;11(1) 6877.

[118] Mykkanen HM, Wasserman RH. Enhanced Absorption of Calcium by Casein Phosphopeptides in Rachitic and Normal Chicks. Journal of Nutrition 1980;110(11) 2141-2148.

[119] Meisel H. Overview on Milk Protein-Derived Peptides. International Dairy Journal 1998;8(5-6) 363-373.

[120] Reynolds EC, Johnson IH. Effect of Milk on Caries Incidence and Bacterial Composition of Dental Plaque in the Rat. Archives of Oral Biology 1981;26 (5) 445-451.

[121] Rosen S, Min DB, Harper DS, Harper WJ, Beck EX, Beck FM. Effect of Cheese with and without Sucrose, on Dental Caries and Recovery of Streptococcus mutans in Rats. Journal of Dental Research 1984;63(6) 894-896.

[122] Harper DS, Osborne JC, Hefferren JJ, Clayton R. Cariostatic Evaluation of Cheeses with Diverse Physical and Compositional Characteristics. Caries Research 1986;20 (2) 123-130.

[123] Walker GD, Cai F, Shen P, Adams GG, Reynolds C, Reynolds EC. Casein Phosphopeptide Amorphous Calcium Phosphate Incorporated into Sugar Confections Inhibits the Progression of Enamel Subsurface Lesions in Situ. Caries Research 2010;44(1) 3-40.

[124] Shaw L, Murray JJ, Burchell CK, Best JS. Calcium and Phosphorus Contents of Plaque and Saliva in Relation to Dental Caries. Caries Research 1983;17 (6) 543-548.

[125] Margolis HC, Moreno EC. Composition of Pooled Plaque Fluid from Caries-Free and Caries-Positve Individuals Following Sucrose Exposure. Journal of Dental Research 1992;71(11) 1776-1784.

[126] Reynolds EC. Remineralization of Enamel Subsurface Lesions by Casein Phosphopeptide-Stabilized Calcium Phosphate Solutions. Journal of Dental Research 1997;76(9) 1587-1595.

[127] Reynolds EC. Anticariogenic Phosphopeptides. US Patent 5015628.

[128] Rose RK, Turner SJ. Fluoride-Induced Enhancement of Diffusion in Streptococcal Model Plaque Biofilms. Caries Research 1998; 32(3) 227-232.

[129] Rose RK, Dibdin GH. Calcium and Water Diffusion in Streptococcal Model Plaques. Archives of Oral Biology 1995;40(5) 385-391. 
[130] Rose RK, Turner SJ, Dibdin GH. Effect of pH and Calcium Concentration on Calcium Diffusion in Streptococcal Model Plaque Biofilms. Archives of Oral Biology 1997;42(12) 795-800.

[131] Shaw JH, Ensfield BJ, Wollman DH. Studies on the Relation of Dairy Products to Dental Caries in Caries-Susceptible Rats. Journal of Nutrition 1959;67(2) 253-273.

[132] Papas AS, Joshi A, Belanger AJ, Kent RL, Palmer CA, De Paola PF. Dietary Models for Root Caries. American Journal of Clinical Nutrition 1995;61(2) 417S-422S.

[133] Ferrazzano GF, Cantile T, Quarto M, Ingenito A, Chianese L, Addeo F. Protective Effect of Yogurt Extract on Dental Enamel Demineralization in Vitro. Australian Dental Journal 2008;53(4) 314-319.

[134] Reynolds EC, Riley PF, Adamson N. A Selective Precipitation Purification Procedure for Multiple Phosphoseryl-Containing Peptides and Methods for their Indentification. Analytical Biochemistry 1994;217(2) 277-284.

[135] Tirelli A, De Noni I, Resmini P. Bioactive Peptides in Milk Products. Italian Journal of Food Science 1997;9(2) 91-98.

[136] Meisel H, Andersson HB, Buhl K, Erbersdobler HF, Schlimme E. Heat-Induced Changes in Casein-Derived Phosphopeptides. Zeitschrift Fur Ernahrungswissenschaft 1991;30(3) 227-232.

[137] Ferranti P, Lilla S, Chianese L, Addeo F. Alternative Nonallelic Deletion is Constitutive of Ruminant $\alpha_{\mathrm{s} 1}$-Casein. Journal of Protein Chemistry 1999;18(5) 595-602.

[138] Juillerat MA, Baechler R, Berrocal R, Chanton S, Scherz JC, Jost R. Tryptic Phosphopeptides from Whole Casein. I. Preparation and Analysis by Fast Protein Liquid Chromatography. Journal of Dairy Research 1989;56(4) 603-611.

[139] Adamson NJ, Reynolds EC. Characterization of Tryptic Casein Phosphopeptides Prepared under Industrially Relevant Conditions. Biotechnology and Bioengineering 1995;45(3) 196-204.

[140] Goepfert A, Meisel H. Semi-Preparative Isolation of Phosphopeptides Derived from Bovine Casein and Dephosphorylation of Casein Phosphopeptides. Nahrung 1996;40(5) 245-248.

[141] Ellegard KH, Gammelgard-Larsen C, Sørensen ES, Fedosovc S. Process Scale Chromatographic Isolation, Characterization and Identification of Tryptic Bioactive Casein Phosphopeptides. International Dairy Journal 1999;9(9) 639-652.

[142] Zhao L, Wang Z, Xu S. Preparation of Casein Phosphorylated Peptides and Casein non-Phosphorylated Peptides using Alcalase. European Food Research and Technology 2007;225(3-4) 579-584.

[143] Reynolds EC. Production of Phosphopeptides from Casein. US Patent 6448374.

[144] Brule G, Roger L, Fauquant J, Piot M. Casein Phosphopeptide Salts. US Patent 5028589.

[145] Naito H, Noguchi T, Sato R, Tsuji K, Hidaka H. Transparent Acid Drink Containing Acid-Soluble Casein Phosphopeptides. US Patent 5405756.

[146] Ramalingam L, Messer LB, Reynolds EC. Adding Casein Phosphopeptide-Amorphous Calcium Phosphate to Sports Drinks to Eliminate in Vitro Erosion. Pediatric Dentistry 2005;27(1) 61-67. 
[147] Tancredi D, Ming D, Holme S. Calcium Phosphate Complex in Acid Containing Chewing Gum. US Patent 8133475.

[148] Walker G, Cai F, Shen P, Reynolds C, Ward B, Fone C, Honda S, Koganei M, Oda M, Reynolds E. Increased Remineralization of Tooth Enamel by Milk Containing Added Casein Phosphopeptide-Amorphous Calcium Phosphate. Journal of Dairy Research 2006;73(1) 74-78.

[149] Kostyra H, Kostyra E. Biologically Active Peptides Derived from Food Proteins. Polish Journal of Food and Nutrition Sciences 1992;1/42(4) 5-17.

[150] Meisel H, Schlimme E. Milk Proteins: Precursors of Bioactive Peptides. Trends in Food Science and Technology 1990;1 41-43.

[151] Rokka T, Syväoja EL, Tuominen J, Korhonen H. Release of Bioactive Peptides by Enzymatic Proteolysis of Lactobacillus GG Fermented UHT Milk. Milchwissensch 1997;52 675-678.

[152] Jarmolowska B, Kostyra E, Krawczuk S, Kostyra H. $\beta$-Casomorphin-7 Isolated from Brie Cheese. Journal of the Science of Food and Agriculture 1999;79(13) 1788-1792.

[153] Muehlenkamp MR, Warthesen JJ. $\beta$-Casomorphins: Analysis in Cheese and Susceptibility to Proteolytic Enzymes from Lactococcus lactic ssp. cremoris. Journal of Dairy Science 1996;79(1) 20-26.

[154] Smacchi E, Gobbetti M. Bioactive Peptides in Dairy Products: Synthesis and Interaction with Proteolytic Enzymes. Food Microbiology 2000;17(2) 129-141.

[155] Ferranti P, Traisci MV, Picariello G, Nasi A, Boschi MS, Falconi C, Chianese L, Addeo F. Casein Proteolysis in Human Milk Tracing the Pattern of Casein Breakdown and the Formation of Potential Bioactive Peptides. Journal of Dairy Research 2004;71(1) 74-87.

[156] Pihlanto-Leppälä A. Bioactive Peptides Derived from Bovine Whey Proteins: Opioid and Ace-Inhibitory Peptides. Trends in Food Science and Technology 2000;11(9-10) 347356.

[157] Bitri L. Optimization Study for the Production of an Opioid-like Preparation from Bovine Casein by Mild Acidic Hydrolysis. International Dairy Journal 2004;14(6) 535539. 